\title{
Sulfonyl-Containing Aldophosphamide Analogues as Novel Anticancer Prodrugs Targeted against Cyclophosphamide-Resistant Tumor Cell Lines
}

\author{
Monish J ain, J unying Fan, Nesrine Z. Baturay, and Chul-Hoon Kwon* \\ Department of Pharmaceutical Sciences, College of Pharmacy and Allied Health Professions, St. J ohn's University, \\ J amaica, New York 11439
}

Received September 22, 2003

\begin{abstract}
A series of sulfonyl-group containing analogues of aldophosphamide (Aldo) were synthesized as potential anticancer prodrugs that liberate the cytotoxic phosphorami de mustards (PM, IPM, and tetrakis-PM) via $\beta$-elimination, a nonenzymatic activation mechanism. Kinetic studies demonstrated that all these compounds spontaneously liberate phosphorami de mustards with half-lives in the range of $0.08-15.2 \mathrm{~h}$ under model physiological conditions in $0.08 \mathrm{M}$ phosphate buffer at $\mathrm{pH} 7.4$ and $37^{\circ} \mathrm{C}$. Analogous to Aldo, the rates of $\beta$-elimination in all compounds was enhanced in reconstituted human plasma under same conditions. The compounds were more potent than the corresponding phosphoramide mustards against V-79 Chinese hamster lung fibroblasts in vitro $\left(\mathrm{IC}_{50}=1.8-69.1 \mu \mathrm{M}\right)$. Several compounds showed excellent in vivo antitumor activity in CD2F 1 mice against both P388/0 (Wild) and P388/CPA (CP-resistant) tumor cell lines.
\end{abstract}

\section{Introduction}

Cyclophosphamide (CP) is a widely used anticancer alkylating agent that requires activation in vivo. The pharmacology and chemistry of CP has been extensively studied and reviewed. ${ }^{1-3} \mathrm{CP}$ undergoes initial hepatic mixed function oxidase-catalyzed activation to 4-hydroxycycl ophosphamide (4-OH CP) that undergoes ring-opening to aldophosphamide (Aldo), followed by liberation of cytotoxic phosphoramide mustard (PM) and acrolein by $\beta$-elimination. The cytotoxic activity of CP is attributed to the reactive aziridinium ion derived from PM, the ultimate alkylating species that cross-links interstrand DNA (Scheme 1). Acrolein, a byproduct of $\beta$-elimination, does not contribute significantly toward anticancer activity of $\mathrm{CP}$, although it is highly toxic to cultured tumor cells. However, acrolein is responsible for hemorrhagic cystitis, a side effect observed during CP therapy.

Release of PM and acrolein from Aldo due to $\beta$-elimination is subject to general base catalysis ${ }^{4}$ and may also be catalyzed by intracellular 3'-5' exonucleases.5,6 The $\beta$-elimination of PM from 4-OHCP/AIdo is also accelerated in plasma due to human serum albumin (HSA). ${ }^{7}$ Such influence of HSA on the pharmacokinetic profiles of 4-OH CP/Aldo and PM metabolites might be of importance in cancer chemotherapy of CP.

One of the primary deactivation pathways of $\mathrm{CP}$ results from oxidation of Aldo to inactive carboxyphosphamide due to enzyme aldehyde dehydrogenase (AIDH) ${ }^{8,9}$ Elevation of either class 1 or class 3 AIDH isozymes has been implicated in devel opment of resistance to 4-OH CP/Aldo but not PM in certain murine and human tumor cell lines. The reason for high oncotoxic

* To whom correspondence should be addressed. Department of Pharmaceutical Sciences, College of Pharmacy and Allied Health Professions, St. J ohn's University, 8000 Utopia Parkway, J amaica, NY 11439. Office: (718)-990-6161 x 5214, fax: (718)-990-6551, e-mail: kwonc@stjohns.edu.
Scheme 1
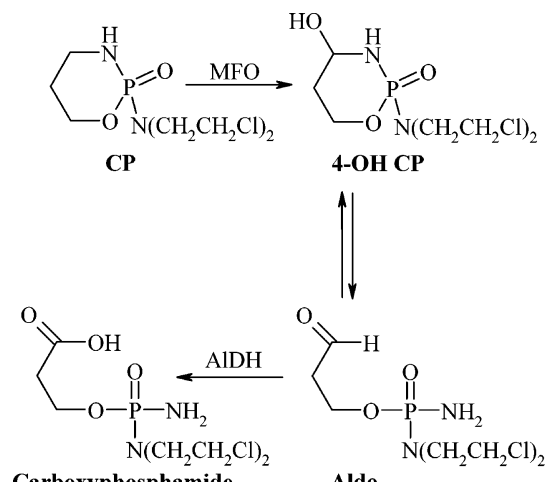

Carboxyphosphamide Aldo
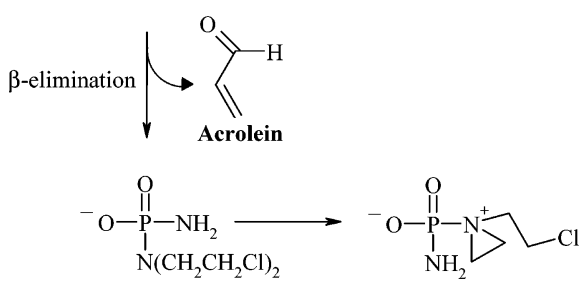

PM Aziridinium ion

selectivity of $\mathrm{CP}$ is unclear and remains to be elucidated. One of the hypotheses suggests that AIDH enzymemediated conversion of Aldo to carboxyphosphamide is less efficient in drug-sensitive tumor cells than normal cells. As a result, Aldo liberates cytotoxic PM preferentially in the tumor cells. ${ }^{8-11}$

I fosfamide (IFA) (Chart 1), a structural isomer of CP, has been developed as a useful anticancer agent with greater activity than CP in certain experimental and human tumors as well as lack of complete crossresistance with CP-resistant tumor cells. ${ }^{1,12-15}$ Analogous to CP, IFA requires metabolic activation to its C-4 hydroxylated metabolite that equilibrates with its aldehyde tautomer (aldoifosfamide) and ultimately yields cytotoxic isophosphoramide mustard (IPM). In contrast to $C P$, IFA suffers substantial deactivation due to 
Chart 1. Structures of I fosfamide, 4-Hydroperoxycyclophosphamide, and Chloroacetaldehyde<smiles>O=P1(NCCCl)OCC=CN1CCCl</smiles>

IFA

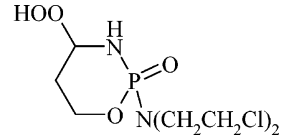

31 (4-Hydroperoxy CP)

$$
{ }_{\mathrm{H}}^{\mathrm{O}} \mathrm{CCH}_{2} \mathrm{Cl}
$$

Chloroacetaldehyde

\section{Scheme 2}

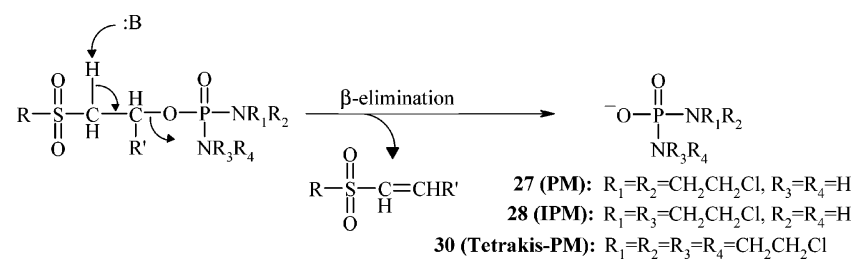

oxidative $\mathrm{N}$-dealkylation metabolism on the chloroethyl side chain to yield inactive metabolites, 2-dechloroethyl ifosfamide and 3-dechloroethyl ifosfamide, al ong with chloroacetal dehyde (Chart 1). It has been suggested that the latter is the cause of the nephrotoxic ${ }^{16-18}$ and neurotoxic ${ }^{19,20}$ side effects of IFA.

Despite the observation that extracellularly delivered PM derivatives ${ }^{21,22}$ have demonstrated activity agai nst experimental tumors, it is well accepted that prodrugs of PM (and IPM) will provide better chemotherapeutic agents due to several reasons. Phosphoramide mustard is chemically labile $\left(\mathrm{t}_{1 / 2}=18 \mathrm{~min}\right.$ in $0.1 \mathrm{M}$ HEPES buffer at $\left.37^{\circ} \mathrm{C}\right)^{23}$ and has a narrow therapeutic index, ${ }^{24}$ and it is shown that extracellularly generated PM would not be readily transported to intracellular environment due to its anionic character at physiological $\mathrm{pH}\left(\mathrm{pK}_{\mathrm{a}}=\right.$ 4.5). ${ }^{3,25}$ Aldophosphamide appears to be an appropriate prodrug of PM that does not require metabolic activation. However, Aldo is difficult to synthesize and isolate. ${ }^{26}$ Therefore, properly designed stable prodrugs of PM and its derivatives can serve as useful anticancer alkylating agents.

Since the first report of Kader and Stirling, ${ }^{27}$ who described 2-(4-toluenesulfonyl)ethyloxycarbonyl (Tsc) as an amine protecting group, a number of al kyl- or arylsubstituted sulfonylethyloxycarbonyl groups have been proposed for carboxyl as well as amino protection. ${ }^{28-30}$ The success of this method is based on the fact that $\beta$-elimination is readily achieved under weakly alkaline conditions, provided the leaving group is situated in a position $\beta$ to a sulfonyl group. The rate of that $\beta$-elimination varies with different substituents in the sulfonyl activating group 31,32 and also changes in the leaving group. ${ }^{33}$ As discussed earlier (Scheme 1), the further activation of Aldo to PM follows the same $\beta$-elimination mechanism except that the electron-withdrawing group is an aldehyde and the leaving group is the cytotoxic PM.

On the basis of the above analogy, substituted sulfonylethyl phosphorodiamidates (Scheme 2) might serve as novel prodrugs of phosphoramide mustards (PM, IPM, and tetrakis-PM) with several potential advantages over CP and related analogues. These prodrugs
Chart 2. Structures of Substituted Sulfonylethyl Phosphorodiamidates

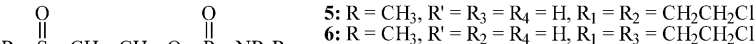

$$
\begin{aligned}
& \text { 8: } \mathrm{R}=\mathrm{CH}_{3}, \mathrm{R}^{\prime}=\mathrm{R}_{2}=\mathrm{R}_{4}=\mathrm{H}_{1}, \mathrm{R}_{1}=\mathrm{R}_{3}=\mathrm{CH}_{2} \mathrm{CH}_{2} \mathrm{Cl}
\end{aligned}
$$

16: $\mathrm{R}=$ phenyl, $\mathrm{R}^{\prime}=\mathrm{R}_{2}=\mathrm{R}_{4}=\mathrm{H}, \mathrm{R}_{1}=\mathrm{R}_{3}=\mathrm{CH}_{2} \mathrm{CH}_{2} \mathrm{Cl}$

1: $\mathrm{R}=$ p-toly, $\mathrm{R}=\mathrm{R}_{3}-\mathrm{R}_{4}-\mathrm{H}_{1}, \mathrm{R}_{1}=\mathrm{R}_{2}-\mathrm{CH}_{2} \mathrm{CH}_{2} \mathrm{Cl}$

21: $\mathrm{R}=$ p-tolyl, $\mathrm{R}-\mathrm{R}_{2}-\mathrm{R}_{4}-\mathrm{H}, \mathrm{R}_{1}-\mathrm{R}_{3}-\mathrm{CH}_{2} \mathrm{CH}_{2} \mathrm{Cl}$

24: $\mathrm{R}=$ p-nitrophenyl, $\mathrm{R}^{\prime}=\mathrm{R}_{2}=\mathrm{R}_{4}=\mathrm{H}, \mathrm{R}_{1}-\mathrm{R}_{3}=\mathrm{CH}_{2} \mathrm{CH}_{2} \mathrm{Cl}$

do not depend on the action of hepatic mixed function oxidases for their activation. Potential differences in routes of metabolism between IFA and sulfonyl prodrugs might lead to decreased side-chain $\mathrm{N}$-dealkylation pathway in the latter, thereby minimizing generation of potentially toxic chloroacetaldehyde. In contrast to Aldo, the designed sulfonyl prodrugs are not likely to be accepted as substrates by the enzyme aldehyde dehydrogenase and therefore have the potential to be active against CP-resistant tumors. Design of nonaldehyde prodrugs that would circumvent AIDH-mediated deactivation and release phosphoramide mustards spontaneously without activation has been previously examined in phenylketoethyl phosphorodiamidate (phenylketophosphamide) ${ }^{10,34}$ or perhydrooxazine analogues ${ }^{35}$ that liberate cytotoxic species directly, or via enamine intermediates, respectively. In both cases, in vitro and in vivo antitumor activity was achieved; however, significant advantages over CP were not reported, with toxicity observed for phenylketophosphamide. ${ }^{10}$

\section{Results and Discussion}

Several substituted sulfonylethyl analogues were examined as novel prodrugs of PM and its derivatives (Chart 2). To optimize rate of $\beta$-elimination, the $\mathbf{R}$ substituent was varied; electron-donating groups such as methyl and p-tolyl would decrease the rate, whereas electron-withdrawing phenyl and p-nitrophenyl groups would increase the rate. The liberated vinyl sulfone may produce toxicity of its own due to the chemical reactivity, which is analogous to the case with acrolein; however, the reactivity could be modulated by introduction of a moderate to bulky substituent, e.g., $\mathrm{R}^{\prime}=$ methyl or phenyl group to the $\beta$-carbon.

Chemistry. A model compound 2-(methylsulfonyl)ethyl 2,4-dinitrophenyl ether (2) was chosen for preliminary studies to determine whether rate of $\beta$-elimination for substituted sulfonylethyl compounds is suitable under physiological conditions. The compound was designed on the basis that the $\beta$-elimination product, 2,4-dinitrophenol (2,4-DNP), has a visible chromophore, and therefore its $\beta$-elimination from $\mathbf{2}$ can be easily quantitated using a spectophotometric technique. Compound $\mathbf{2}$ was synthesized by first reacting 2-(methylthio)ethanol with 2,4-dinitrofluorobenzene and $\mathrm{Et}_{3} \mathrm{~N}$ to give 1, which in turn was oxidized by hydrogen peroxide/ ammonium molybdate in acetone (Scheme 3 ).

The 2-thioethanol starting materials for generation of sulfonylethyl phosphorodiamidates were either available commercially or prepared according to published procedures. Reactions of thiocresol or p-nitrothiophenol with 2-chloroethanol gave 2-thioethanols $\mathbf{1 7}$ and 22, respectively. Reaction of 1-mercapto-2-propanol with methyl iodide yielded $\mathbf{9}$, and reaction of styrene oxide with sodium methylthiolate provided $\mathbf{1 2}$. 
Scheme $3^{a}$

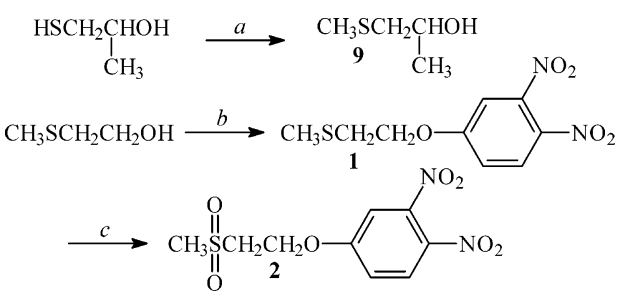

a Reagents: (a) $\mathrm{CH}_{3} \mathrm{l}, \mathrm{NaOH}$; (b) 2,4-dinitrofluorobenzene, $\mathrm{Et}_{3} \mathrm{~N}$; (c) $\mathrm{H}_{2} \mathrm{O}_{2}$, ammonium molybdate.

\section{Scheme $4^{\mathrm{a}}$}

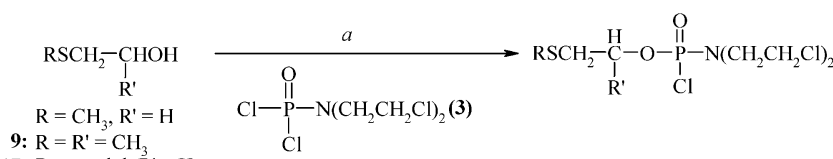

$$
\begin{aligned}
& \text { 17: } \mathrm{R}=\text { p-tolyl, } \mathrm{R}^{\prime}=
\end{aligned}
$$

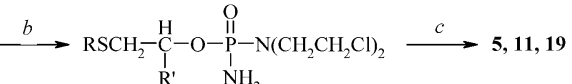

$$
\begin{aligned}
& \text { 4: } \mathrm{R}=\mathrm{CH}_{3}, \mathrm{R}^{\prime}=\mathrm{H} \\
& \text { 10: } \mathrm{R}=\mathrm{R}^{\prime}=\mathrm{CH}_{3} \\
& \text { 18: } R=p \text {-tolyl, } R^{\prime}=H
\end{aligned}
$$

a Reagents: (a) $\mathrm{NaH}$, anhyd THF ; (b) $\mathrm{NH}_{3}$; (c) $\mathrm{H}_{2} \mathrm{O}_{2}$, ammonium molybdate.

\section{Scheme $5^{a}$}

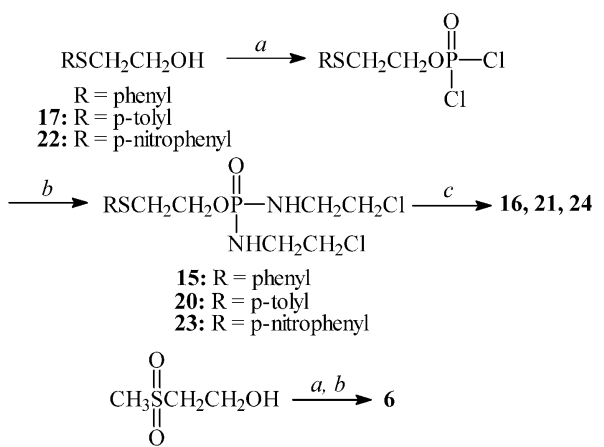

a Reagents: (a) $\mathrm{P}(\mathrm{O}) \mathrm{Cl}_{3}, \mathrm{Et}_{3} \mathrm{~N}, \mathrm{CH}_{2} \mathrm{Cl}_{2}$, or benzene; $\left(\mathrm{HCl} \cdot \mathrm{H}_{2} \mathrm{NCH}_{2-}\right.$ $\mathrm{CH}_{2} \mathrm{Cl}, \mathrm{Et}_{3} \mathrm{~N}$, oe benzene; (c) $\mathrm{H}_{2} \mathrm{O}_{2}$, ammonium molybdate.

The prodrugs contained either $\mathrm{N}, \mathrm{N}$-bis(2-chloroethyl) $(5,11$, and 19$)$ or $\mathrm{N}^{\prime} \mathrm{N}^{\prime}$-bis (2-chloroethyl) $(6,16,21$, and 24) phosphorodiamidates that upon $\beta$-elimination would release the bis-alkylating mustard PM or IPM (Scheme $2)$, respectively. The release of potentially more potent alkylating agent tetrakis-PM (Scheme 2) was sought by design of compounds containing $\mathrm{N}, \mathrm{N}, \mathrm{N}^{\prime}, \mathrm{N}^{\prime}$-tetrakis(2chloroethyl) phosphorodiamidate $(\mathbf{8}, \mathbf{1 4}$, and $\mathbf{2 6})$. Successive reaction of appropriate 2-thioethanol with sodium hydride, N,N-bis(2-chloroethyl)phosphoramidic dichloride, and ammonia gave $\mathrm{N}, \mathrm{N}$-bis(2-chloroethyl)phosphorodiamidate intermediates $(\mathbf{4}, \mathbf{1 0}$, and 18) (Scheme 4). Alternatively, the 2-thioethanol starting materials were treated with phosphorus oxychloride, followed by reaction of the mixture with 2 equiv of 2-chloroethylami ne to yield N,N'-bis(2-chloroethyl) (15, 20, and 23) intermediates (Scheme 5). The obtained thioethyl N,N-bis(2-chl oroethyl)/N,N'-bis(2-chloroethyl) intermediates were oxidized with excess $\mathrm{H}_{2} \mathrm{O}_{2}$ and catalytic ammonium molybdate to give corresponding sulfonylethyl phosphorodiamidates.

Reaction of 2-(methylthio)ethanol with phosphoryl chloride and 2-chloroethylamine did not yield the desired thioethyl N,N'-bis(2-chloroethyl)phosphorodiamidate intermediate; ther efore, the synthetic strategy was

\section{Scheme $6^{a}$}

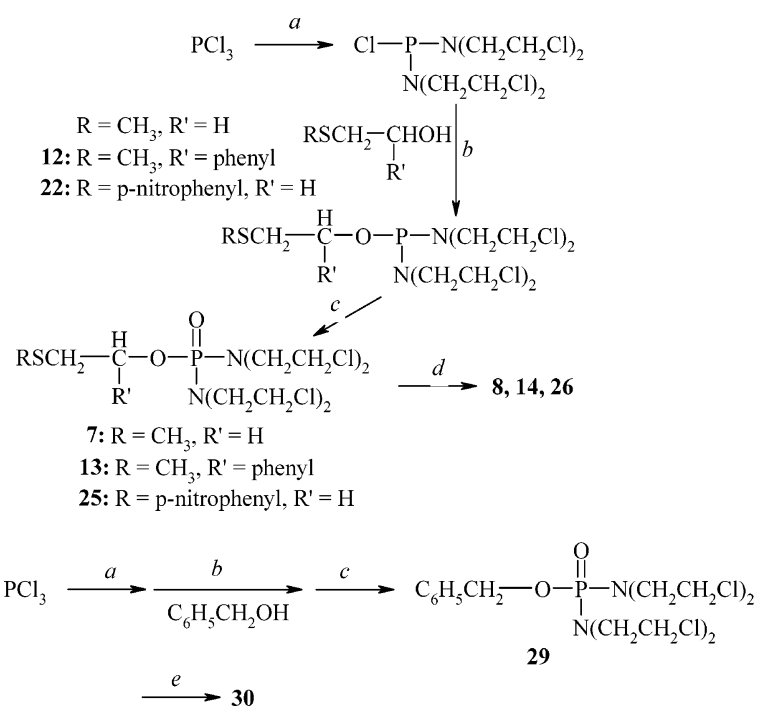

a Reagents: (a) $\mathrm{HCl} \cdot \mathrm{HN}\left(\mathrm{CH}_{2} \mathrm{CH}_{2} \mathrm{Cl}\right)_{2}, \mathrm{Et}_{3} \mathrm{~N}, \mathrm{CH}_{2} \mathrm{Cl}_{2}$; (b) $\mathrm{Et}_{3} \mathrm{~N}$, $\mathrm{CH}_{2} \mathrm{Cl}_{2}$ (c) t-BuOOH; (d) $\mathrm{H}_{2} \mathrm{O}_{2}$, ammonium molybdate; (e) $\mathrm{Pd} / \mathrm{C}$, $\mathrm{H}_{2}, 1 \mathrm{~atm}$.

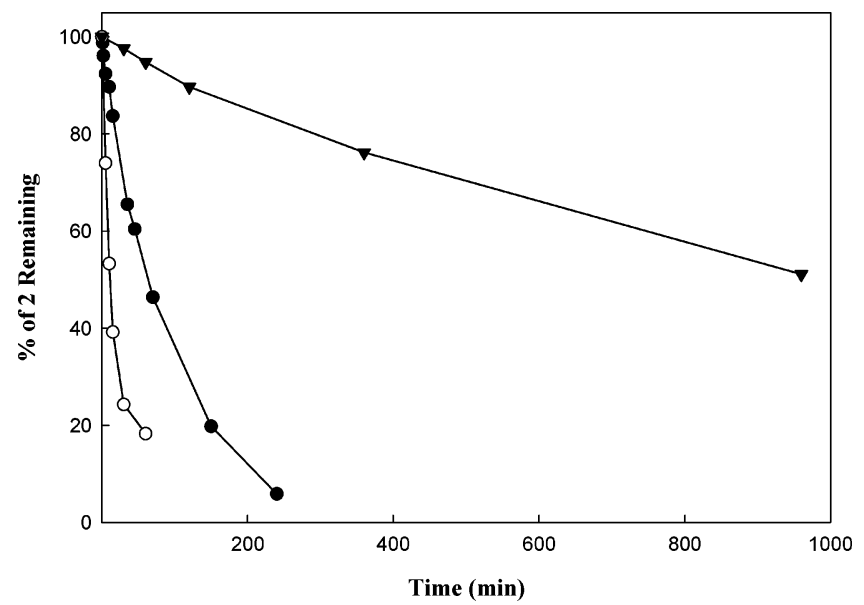

Figure 1. $\beta$-Elimination profile of $\mathbf{2}$ in $0.08 \mathrm{M}$ phosphate buffer at $\mathrm{pH} 6.4(\boldsymbol{\nabla}), 7.4(\bullet)$, and $8.4(\mathrm{O})$ at $37{ }^{\circ} \mathrm{C}$.

modified in case of analogue $\mathbf{6}$. Reaction of 2-(methylsulfonyl)ethanol with phosphoryl chloride and 2-chloroethylamine afforded 6 directly (Scheme 5).

Phosphorus trichloride was sequentially reacted with 2 equiv of bis(2-chloroethyl)amine and the appropriate alcohol, and the resulting phosphorodiamidite was oxidized with tert-butyl hydroperoxide to give intermediates thioethyl $\mathrm{N}, \mathrm{N}, \mathrm{N}^{\prime}, \mathrm{N}^{\prime}$-tetrakis(2-chloroethyl) phosphorodiamidates 7, 13, and 25 or benzyl $\mathrm{N}, \mathrm{N}, \mathrm{N}^{\prime}, \mathrm{N}^{\prime}$ tetrakis(2-chloroethyl) phosphorodiamidate 29. The obtained thioethyl intermediates were oxidized with $\mathrm{H}_{2} \mathrm{O}_{2}$ /ammonium molybdate to afford the corresponding sulfonyl products $\mathbf{8}, \mathbf{1 4}$, and $\mathbf{2 6}$. Reduction of $\mathbf{2 9}$ yielded tetrakis phosphoramide mustard $\mathbf{3 0}$ (Scheme 6).

Stability Studies. Model sulfonyl compound $\mathbf{2}$ underwent base-catalyzed $\beta$-elimination of 2,4-DNP with half-life $\left(\mathrm{t}_{1 / 2}\right)$ of $13.9 \mathrm{~min}$ at $\mathrm{pH} 8.4,68 \mathrm{~min}$ at $\mathrm{pH} 7.4$, and $19.25 \mathrm{~h}$ at $\mathrm{pH} 6.4$ in $0.08 \mathrm{M}$ phosphate buffer at 37 ${ }^{\circ} \mathrm{C}$ (Figure 1). Additional studies with corresponding sulfide $\mathbf{1}$ at similar $\mathrm{pH}$ values showed that the anal ogue was stable for at least $24 \mathrm{~h}$, thereby confirming the importance of sulfonyl moiety as the activating group in the $\beta$-elimination process. Having established that $\mathbf{2}$ 
Table 1. Half-Lives under Model Physiological Conditions and in Vitro Cytotoxicity Profiles against V-79 Cellsa for Sulfonyl Prodrugs and Phosphoramide Mustards

\begin{tabular}{lccr}
\hline & \multicolumn{2}{c}{ half-life (h) $^{\mathrm{b}}$} \\
\cline { 2 - 3 } & $\begin{array}{c}\text { phosphate } \\
\text { buffer }\end{array}$ & $\begin{array}{c}\text { human } \\
\text { plasmad }\end{array}$ & \\
\hline $\mathbf{5}$ & $5.9 \pm 0.6$ & $2.2(2.3 \pm 0.3)^{\mathrm{e}}$ & $56.5 \pm 5.6$ \\
$\mathbf{6}$ & $6.4 \pm 0.6$ & $2.2 \pm 0.1$ & $68.0 \pm 9.7$ \\
$\mathbf{8}$ & $7.2 \pm 1.2$ & $1.6 \pm 0.1$ & $24.1 \pm 3.3$ \\
$\mathbf{1 1}$ & $15.2 \pm 0.3$ & $6.7 \pm 0.7$ & $69.1 \pm 9.8$ \\
$\mathbf{1 4}$ & $1.8 \pm 0.2$ & $1.0 \pm 0.1$ & $15.2 \pm 2.4$ \\
$\mathbf{1 6}$ & $6.4 \pm 0.3$ & $2.6 \pm 0.2$ & $13.9 \pm 1.5$ \\
$\mathbf{1 9}$ & $12.8 \pm 2.8$ & $4.8 \pm 0.5$ & $11.5 \pm 1.1$ \\
$\mathbf{2 1}$ & $12.1 \pm 1.1$ & $4.4 \pm 0.4$ & $9.5 \pm 2.0$ \\
$\mathbf{2 4}$ & $0.08 \pm 0.01$ & $<0.01$ & $2.1 \pm 0.5$ \\
$\mathbf{2 6}$ & $0.69 \pm 0.02$ & $0.37 \pm 0.16$ & $1.8 \pm 0.2$ \\
$\mathbf{4 - O H}$ CP/Aldo & $0.75^{\mathrm{g}}$ & $0.25^{\mathrm{g}}$ & $3.3 \pm 0.8$ \\
$\mathbf{2 7}$ (PM) & $0.30^{\mathrm{h}}$ & & $77.0 \pm 0.0$ \\
$\mathbf{2 8}$ (IPM) & $1.0^{\mathrm{i}}$ & & $60.9 \pm 5.8$ \\
$\mathbf{3 0}$ (Tetrakis-PM) & & & $42.6 \pm 4.3$ \\
\hline
\end{tabular}

a Drug exposure time: $3 \mathrm{~h}$. b Mean \pm SD of three experiments. c $0.08 \mathrm{M}$ phosphate buffer. $d$ Human plasma reconstituted in 0.08 $\mathrm{M}$ phosphate buffer, $\mathrm{pH} 7.4,37^{\circ} \mathrm{C}$. ${ }^{\mathrm{e}} \mathrm{Half}$-life in human serum albumin (Fraction $\mathrm{V}, 60 \mathrm{mg} / \mathrm{mL}$ ) in $0.08 \mathrm{M}$ phosphate buffer, $\mathrm{pH}$ $7.4,37^{\circ} \mathrm{C}$. ${ }^{\mathrm{f}} 4-\mathrm{OOH} \mathrm{CP}$, a precursor form, that readily converts to 4-OH CP/Aldo in aqueous solution was used for cytotoxicity testing. Half-life values at $\mathrm{pH} 7.4,37{ }^{\circ} \mathrm{C}$ in $90.1 \mathrm{M}$ phosphate buffer, $\mathrm{h} 0.1$ $\mathrm{M}$ HEPES buffer, and ${ }^{\mathrm{i}} 0.2 \mathrm{M}$ phosphate buffer obtained from literature. ${ }^{23}$

undergoes $\beta$-elimination under physiological $\mathrm{pH}$, we synthesized several substituted sulfonylethyl phosphorodiamidates as prodrugs (Chart 2), anticipating their ability to yield cytotoxic phosphoramide mustards as anticancer agents (Scheme 2 ). Rates of $\beta$-elimination of phosphoramide mustards in sulfonyl prodrugs were determined under model physiological conditions by monitoring the rate of disappearance of prodrug upon incubation in $0.08 \mathrm{M}$ phosphate buffer, $\mathrm{pH} 7.4$ and 37 ${ }^{\circ} \mathrm{C}$, with the use quantitative TLC technique. Results are presented in Table 1 . The half-lives of 2-(methylsulfonyl)ethyl phosphorodiamidates $(\mathbf{5}, \mathbf{6}$, and $\mathbf{8}$ ) were essentially similar (5.9-7.2 h) and showed greater stability than model compound $\mathbf{2}$, apparently due to change of the nature of the leaving group, i.e., 2,4-DNP versus phosphorodiamidic acid. Changes within phosphorodiamidate moi ety itself did not affect the elimination rate and were found similar for N,N-bis(2-chloroethyl), $\mathrm{N}, \mathrm{N}^{\prime}$-bis(2-chl oroethyl), or $\mathrm{N}, \mathrm{N}, \mathrm{N}^{\prime}, \mathrm{N}^{\prime}$-tetrakis(2chloroethyl)phosphorodiamidic acid leaving groups. The phenylsulfonyl compound $\mathbf{1 6}$ showed a half-life of $6.4 \mathrm{~h}$ that was comparable to that of methylsulfonyl analogues. The electron-donating p-tolylsulfonyl substituent in analogues $\mathbf{1 9}$ and $\mathbf{2 1}$ reduces acidity of the $\alpha$-proton, thereby decreasing the $\beta$-elimination reaction rate $\left(\mathrm{t}_{1 / 2}\right.$ $=$ approximately $12 \mathrm{~h}$ ) as compared to 16. Conversely, the electron-withdrawing p-nitrophenylsulfonyl substituent in $\mathbf{2 4}$ and $\mathbf{2 6}$ enhanced the $\beta$-elimination rate and showed a much shorter half-life $\left(\mathrm{t}_{1 / 2}=0.08\right.$ and 0.69 $\mathrm{h}$, respectively) than 16. The $\beta$-methyl-substituted compound $\mathbf{1 1}$ with a half-life of $\mathbf{1 5 . 2} \mathrm{h}$ appeared more stable than the corresponding non- $\beta$-substituted analogues. The $\beta$-phenyl-substituted prodrug 14 showed a short half-life of $1.8 \mathrm{~h}$. The observation that $\beta$-methyl substituent decreases and $\beta$-phenyl substituent enhances the $\beta$-elimination rate in sulfonylethyl compounds is consistent with previously reported data. ${ }^{36}$ The el ectron-inductive effects of $\beta$-methyl that diminish acidity of the $\alpha$-proton, in conjunction with steric hindrance of $\beta$-methyl to the incoming nucleophile, may explain slower base-catalyzed $\beta$-elimination in 11. The underlying mechanism for enhancement of $\beta$-elimination due to the $\beta$-phenyl substituent could not be readily explained. Presumably, the el ectron-inductive effects of the $\beta$-phenyl, that enhance acidity of the $\alpha$-proton and accelerate elimination, outweigh the steric hindrance effects it offers to the incoming nucleophile.

Among sulfonyl analogues, only the p-nitrophenylsulfonyl compounds $\mathbf{2 4}$ and $\mathbf{2 6}$ showed comparable or faster $\beta$-elimination rates than 4-OH CP/Aldo. Other sulfonyl analogues showed greater stability than Aldo under model physiological conditions. The data suggests that sulfonyl analogues are chemically stable and may serve as useful prodrugs of phosphoramide mustards. The activating group confers the elimination reactivity in the following order: p-nitrophenylsulfonyl $\geq$ aldehyde $>$ phenylsulfonyl $\approx$ methylsulfonyl > p-tolylsulfonyl.

It might be argued that sulfonylethyl phosphorodiamidates liberate phosphoramide mustards and as a result disappear under model physiological conditions due to mechanisms different than the suggested $\beta$ elimination pathway such as hydrolysis of the phosphate ester linkage of the phosphorodiamidate group. Thi oethyl phosphorodiamidate analogues such as 4 and 18 lack a sulfonyl group and should be stable toward $\beta$-elimination. These analogues were found to be stable for at least $16 \mathrm{~h}$ in $0.08 \mathrm{M}$ phosphate buffer $(\mathrm{pH} 7.4,37$ $\left.{ }^{\circ} \mathrm{C}\right)$, suggesting that phosphate ester hydrolysis does not contribute to the disappearance of sulfonylethyl phosphorodiamidates.

Aldophosphami de undergoes approximatel y 250-fold faster decomposition in plasma than in phosphate buffer alone, and human serum al bumin (HSA) was identified as the catalyst responsible for accelerated $\beta$-elimination of PM from Aldo. ${ }^{7}$ By analogy, since, sulfonyl analogues are expected to employ the same $\beta$-el imination mechanism to generate phsophoramide mustards, they were examined for similar enhanced decomposition behavior in plasma. Interestingly, sulfonyl analogues underwent accelerated decomposition in plasma (and HSA for 5) than in phosphate buffer with the extent of acceleration similar to that observed in Aldo.

The catalytic rate constants $\mathrm{k}_{\text {cat }}$ under $\mathrm{pH} 7.4$ and 37 ${ }^{\circ} \mathrm{C}$ for disappearance of 5 in phosphate buffer (0.08 M) and human serum albumin (HSA, mol. wt. 66000 Da; actual concentration $48 \mathrm{mg} / \mathrm{mL}$ or $7.3 \times 10^{-4} \mathrm{M}$ ) were 1.46 and $253 \mathrm{M}^{-1} \mathrm{~h}^{-1}$, respectively, where, $\mathrm{k}_{\text {cat }}=\mathrm{k}_{\mathrm{obs}} /$ concentration of phosphate buffer or concentration of HSA. In case of phosphate, $k_{\text {obs }}\left(1.17 \times 10^{-1} \mathrm{~h}^{-1}\right)$ was obtained from stability studies. The $\mathrm{k}_{\mathrm{obs}}\left(3.01 \times 10^{-1}\right.$ $\mathrm{h}^{-1}$ ) in HSA was corrected for contribution from phosphate and the result $\left(3.01 \times 10^{-1} \mathrm{~h}^{-1}-1.17 \times 10^{-1} \mathrm{~h}^{-1}\right.$ $=1.84 \times 10^{-1} \mathrm{~h}^{-1}$ ) used to calculate $\mathrm{k}_{\text {cat }}$ in HSA. Based on $\mathrm{k}_{\text {cat }}$ values, the rate of decomposition of $\mathbf{5}$ due to HSA is approximately 175-fold faster than in phosphate buffer.

Analogous to Aldo, HSA appears to be the catalytic component of human plasma that enhances $\beta$-eliminati on in $\mathbf{5}$ and other sulfonyl analogues. The significance of albumin catalytic activity in CP metabolism and its possible role in oncotoxic specificity of $\mathrm{CP}$ remains to be explored. However, the sulfonyl analogues undergoing similar acceleration of PM generation in albumin 
might share the pharmacokinetic properties of $4-\mathrm{OH} \mathrm{CP} /$ Aldo and PM and also share their therapeutic profile.

In Vitro Cytotoxicity. Sulfonyl analogues were evaluated for in vitro cytotoxicity against Chinese hamster lung fibroblast (V-79) cells in a clonogenic assay using a $3 \mathrm{~h}$ drug exposure period. The drug concentration that produced a $50 \%$ reduction in clonogenic survival $\left(\mathrm{IC}_{50}\right)$ was determined from the slope of the log survival versus concentration curves. The results are presented in Table 1. Sulfonyl analogues are expected to exert their cytotoxicity by the release of phosphoramide mustards; therefore, their ability to enter the cells and the rate at which they liberate phosphoramide species would influence their cytotoxic potential.

Methylsulfonyl analogues $(\mathbf{5}, \mathbf{6}, \mathbf{8}, \mathbf{1 1}$, and $\mathbf{1 4})$ showed appreciable cytotoxic activity with $\mathrm{IC}_{50}$ values ranging between $15.2 \mu \mathrm{M}$ and $68.0 \mu \mathrm{M}$. Increase in cytotoxic potential was observable due to the presence of additional nitrogen mustard in $\mathbf{8}$ or enhancement in lipophilicity and $\beta$-elimination rates as in 14. In general, irrespective of their $\beta$-elimination rates, aromatic ringsubstituted sulfonyl anal ogues showed greater cytotoxic activity $\left(\mathrm{IC}_{50}=1.8-13.9 \mu \mathrm{M}\right)$ than the corresponding methylsulfonyl compounds. Presence of aromatic group confers li pophilic character to the analogue and therefore may allow its easy transport across tumor cell membrane. In comparison to $\mathbf{5 , 6}$, and $\mathbf{8}$, the increased cytotoxicity for 16, 19, and $\mathbf{2 1}$ may be attributed to their greater lipophilicity, whereas nitrophenylsulfonyl compounds $\mathbf{2 4}$ and $\mathbf{2 6}$ show substantial cytotoxicity, most likely due to their lipophilic character as well as rapid $\beta$-elimination rates. Nitrophenylsulfonyl anal ogues were found even more potent than 4-hydroperoxy CP control that spontaneously generates 4-OH CP/Aldo in aqueous media. All sulfonyl analogues showed better cytotoxic activity $\left(\mathrm{IC}_{50}=1.8-69.1 \mu \mathrm{M}\right)$ than the corresponding phsophoramide mustards $\left(\mathrm{IC}_{50}=42.6-77.0 \mu \mathrm{M}\right)$, thereby suggesting that neutral sulfonyl analogues might serve as useful transport forms that liberate cytotoxic phosphoramide mustards intracellularly.

In Vivo Antitumor Activity. Antitumor activity of sulfonyl anal ogues was assessed in vivo against P388/0 (Wild) and P388/CPA (CP-resistant) leukemia in mice and efficacy measured by increase in life span. Analogues were tested at three doses of 100, 200, and 400 $\mathrm{mg} / \mathrm{kg}$. I sophosphoramide mustard (IPM) at its maximum tolerable dose $\left(\mathrm{LD}_{10}\right)$ of $100 \mathrm{mg} / \mathrm{kg}$ or $\mathrm{CP}$ at 200 $\mathrm{mg} / \mathrm{kg}$ dose served as positive controls. ${ }^{33}$ The results are presented in Table 2.

All the sulfonyl analogues tested for in vivo antitumor activity against P388/0 (Wild) and P388/CPA (CPresistant) leukemia in mice were active, thereby supporting the hypothesis that sulfonylethyl phosphorodiamidates can serve as useful prodrugs of phosphoramide mustards. Analogues 5, 6, 19, 24, and $\mathbf{2 6}$ showed in vivo antitumor activity against P388/0. At $200 \mathrm{mg} / \mathrm{kg}$ dose, $\mathbf{2 4}$ and $\mathbf{2 6}$ showed similar or better antitumor activity against P388/0 than CP with 2/5 long-term survivors for both analogues. At $400 \mathrm{mg} / \mathrm{kg}$ level, 5, 6 (1/5 longterm survivor), and $\mathbf{1 9}$ showed equivalent or better activity than I PM. Only $\mathbf{2 4}$ and $\mathbf{2 6}$ displayed toxicity at $400 \mathrm{mg} / \mathrm{kg}$, whereas I PM was toxic at $200 \mathrm{mg} / \mathrm{kg}$ level.

Consistent with the original hypothesis, sulfonylethyl phosphorodiamidates were effective anticancer agents
Table 2. Antitumor Activity of Sulfonylethyl

Phosphorodiamidates against P388/0 and P388/CPA Leukemia in Vivo

\begin{tabular}{|c|c|c|c|c|c|c|}
\hline \multirow[b]{3}{*}{ compound } & \multicolumn{6}{|c|}{$\%$ ILSa } \\
\hline & \multicolumn{3}{|c|}{$\begin{array}{l}\text { P388/0 (wild): } \\
\text { dose (mg/kg) }\end{array}$} & \multicolumn{3}{|c|}{$\begin{array}{c}\text { P388/CPA (resistant): } \\
\text { dose }(\mathrm{mg} / \mathrm{kg})\end{array}$} \\
\hline & 100 & 200 & 400 & 100 & 200 & 400 \\
\hline 5 & 36 & 73 & 91 & 28 & 52 & 100 \\
\hline 6 & 33 & 52 & $100(1 / 5)$ & 20 & 84 & 108 \\
\hline 8 & 10 & 10 & 30 & 12 & 28 & 60 \\
\hline 11 & 10 & 10 & 30 & 12 & 20 & 36 \\
\hline 14 & 10 & 20 & 20 & 4 & 20 & 60 \\
\hline 16 & 33 & 33 & 33 & 20 & 28 & 60 \\
\hline 19 & 20 & 50 & 90 & 28 & 28 & 44 \\
\hline 21 & 23 & 14 & 23 & 4 & 12 & 36 \\
\hline 24 & 71 & $138(2 / 5)$ & toxic & 60 & $92(2 / 5)$ & \\
\hline 26 & 100 & $120(2 / 5)$ & toxic & $84(1 / 5)$ & $68(3 / 5)$ & tox \\
\hline IPM & 92 & toxic & & & & \\
\hline $\mathrm{CP}$ & & $128(2 / 5)$ & & & toxic & \\
\hline
\end{tabular}

a Numbers in parentheses indicate long-term (33-day) survivors.

against P388/CPA in vivo with considerably superior activity as compared to $C P$. Whereas $C P$ did not show activity against P388/CPA, p-nitrophenylsulfonyl analogues $\mathbf{2 4}$ and $\mathbf{2 6}$ were most potent with $2 / 5$ and 3/5 long-term survivors, respectively, at $200 \mathrm{mg} / \mathrm{kg}$ dose. Similar to activity against P388/0, 5 and $\mathbf{6}$ also demonstrated excellent antitumor activity against P388/ CPA. Compounds 8, 14, and 16 were more potent against CP-resistant P388 than wild-type P388. P388/ CPA was not cross-resistant toward any of the tested sulfonyl analogues, most likely due to nonsusceptibility of sulfonyl analogues to AIDH-mediated deactivation. Among the tested prodrugs, only $\mathbf{2 4}$ and $\mathbf{2 6}$ displayed toxicity at the highest level, and better antitumor activity is expected from other agents against both P388/0 and P388/CPA at higher doses. In view of these data, it is reasonable to suspect that AIDH-mediated preferential deactivation of alodophosphamide in normal versus tumor cells may not be the sole contributing factor that governs selective in vivo antitumor activity. Detailed studies with sulfonyl prodrugs may provide additional insights into the role of AIDH with respect to mechanisms of tumor-selective toxicity of prodrugs of phosphoramide mustards.

\section{Conclusions}

Several sulfonyl group-containing stable analogues of aldophosphamide (Aldo) have been examined as novel prodrugs of phosphoramide mustard (PM) derivatives. These compounds do not require enzyme-mediated activation but require only base-catalyzed $\beta$-elimination to liberate cytotoxic species.

Anal ogues with electron-withdrawing substituents on the sulfonyl group showed faster $\beta$-elimination rates as compared to analogues containing electron-donating substituents. Despite substituent dependent variation in decomposition half-lives of sulfonyl compounds, the elimination behavior was found strikingly similar to Aldo such that acceleration in $\beta$-elimination rate was observed in the presence of human plasma for all analogues. The in vitro cytotoxicity potential of the sulfonyl analogues seemed to rely on their lipophilicity as well as the elimination rate characteristics. All sulfonyl analogues demonstrated in vivo antitumor activity. Furthermore, in vivo antitumor activity was 
equal to or better than that of $\mathrm{CP}$ against wild-type P388 cells. Consistent with the original hypothesis, sulfonyl prodrugs were substantially superior to $\mathrm{CP}$ against CP-resistant P388 cell line in vivo.

\section{Experimental Section}

Melting points were determined on a Thomas-Hoover capillary melting point apparatus and were uncorrected. ${ }^{1} \mathrm{H}$ NMR spectra were recorded on a Varian EM-360 (60 MHz) instrument, and chemical shifts are reported as $\delta$ values (ppm) downfield from tetramethylsilane as an internal standard. NMR abbreviations used are as follows: s (singlet), d (doublet), t (triplet), q (quartet), $m$ (multiplet). Elemental analyses were performed by Atlantic Microlab, I nc. Norcross, GA. Silica gel GF plates (Analtech) were used for TLC $(250 \mu \mathrm{m}, 2.5 \times 10$ $\mathrm{cm})$ and preparative TLC $(1000 \mu \mathrm{m}, 20 \times 20 \mathrm{~cm})$. Silica gel (40 $\mu \mathrm{m}$, Baker) was used for flash column chromatography. NBP spray was used for the detection of potential alkylating compounds as follows: the plates were sprayed with 5\% 4-(pnitrobenzyl)pyridine (NBP) in acetone, heated at $100{ }^{\circ} \mathrm{C}$ for 5 min (20 min for the kinetic studies), and sprayed with 5\% methanolic $\mathrm{KOH}$. Alkylating agents are indicated by the appearance of a blue chromophore. Spectrophotometric analysis was performed on a Milton Roy spectronic 301 spectrophotometer. Quantitative TLC analyses were done on an Analtech Uniscan Video Densitometer. All organic reagents and solvents were reagent grade and purchased from commercial vendors.

2-(Methylthio)ethyl 2,4-dinitrophenyl ether (1) was prepared according to the published procedure ${ }^{37}$ with some modifications. 2-(Methylthio)ethanol ( $1.2 \mathrm{~g}, 1.2 \mathrm{~mL}, 13 \mathrm{mmol}$ ) and triethylamine $(1.5 \mathrm{~mL}, 10.8 \mathrm{mmol})$ were added to 2,4 dinitrofluorobenzene $(1.0 \mathrm{~g}, 5.3 \mathrm{mmol})$. Benzene $(25 \mathrm{~mL})$ was then added and the dark reaction mixture stirred overnight at room temperature. The reaction mixture was then heated under reflux with stirring for $6 \mathrm{~h}$, cooled, and acidified with $15 \mathrm{~mL}$ of $1 \mathrm{~N} \mathrm{HCl}$. The organic phase was separated and dried over anhydrous sodium sulfate and the filtrate evaporated to give a yell ow colored residue. The residue was dissolved in 25 $\mathrm{mL}$ of diethyl ether and washed with $2 \mathrm{~N}$ aqueous $\mathrm{NaHCO}_{3}$ $(4 \times 15 \mathrm{~mL})$. The ether layer was evaporated in vacuo and the residue recrystallized in methanol to afford $0.45 \mathrm{~g} \mathrm{(33 \%}$ yield) of $\mathbf{1}$ as a light yellow crystalline product: $\mathrm{mp} \mathrm{53-55}$ ${ }^{\circ} \mathrm{C}$; TLC $\mathrm{R}_{\mathrm{f}} 0.57$ in EtOAc/hexane (1:1); ${ }^{1} \mathrm{H}$ NMR $\left(\mathrm{CDCl}_{3}\right) \delta 2.15$ $(\mathrm{s}, 3 \mathrm{H}), 2.86(\mathrm{t}, \mathrm{J}=6.6 \mathrm{~Hz}, 2 \mathrm{H}), 4.33(\mathrm{t}, \mathrm{J}=9 \mathrm{~Hz}, 2 \mathrm{H}), 7.15$ $(\mathrm{d}, \mathrm{J}=14.4 \mathrm{~Hz}, 1 \mathrm{H}), 8.31(\mathrm{~d}, \mathrm{~J}=16.2 \mathrm{~Hz}, 1 \mathrm{H}), 8.66(\mathrm{~s}, 1 \mathrm{H})$.

2-(Methylsulfonyl)ethyl 2,4-dinitrophenyl ether (2) was prepared according to the procedure of $\mathrm{H}$ ardy et al. ${ }^{28}$ with some modifications. The corresponding sulfide $1(0.39 \mathrm{~g}, 1.5$ $\mathrm{mmol})$ was dissolved in acetone $(20 \mathrm{~mL})$ and water $(10 \mathrm{~mL})$, treated with aqueous hydrogen peroxide (30 wt \%, $21 \mathrm{~mL}, 200$ $\mathrm{mmol}$ ), and mixed with $0.3 \mathrm{M}$ ammonium molybdate ( $3 \mathrm{~mL}$ ). The dark red reaction mixture was stirred for $3 \mathrm{~h}$ at room temperature after which the acetone was evaporated in vacuo and the residue partitioned between $\mathrm{CH}_{2} \mathrm{Cl}_{2}(50 \mathrm{~mL})$ and water (50 mL). The aqueous phase was washed with $\mathrm{CH}_{2} \mathrm{Cl}_{2}(3 \times 25$ $\mathrm{mL}$ ). The pool ed $\mathrm{CH}_{2} \mathrm{Cl}_{2}$ extracts were washed with saturated brine $(2 \times 75 \mathrm{~mL})$ and dried over anhydrous sodium sulfate, and the filtrate was evaporated under reduced pressure to yield pale yellow, shiny plates. The product separated out as white solids during an attempt to dissolve the crude product in $25 \mathrm{~mL}$ of THF for purification by preparative TLC. The solids were filtered and dried to afford $0.2 \mathrm{~g}$ of pure $\mathbf{2}(47 \%$ yield): $m p ~ 150-155^{\circ} \mathrm{C}$; TLC $R_{f} 0.50$ in EtOAc/hexane (1:2); ${ }^{1} \mathrm{H}$ NMR $\left(\mathrm{CDCl}_{3} / \mathrm{DMSO} 5: 1\right) \delta 3.12(\mathrm{~s}, 3 \mathrm{H}), 3.62(\mathrm{t}, \mathrm{J}=3.6 \mathrm{~Hz}$, $2 \mathrm{H}), 4.76(\mathrm{t}, \mathrm{J}=8.4 \mathrm{~Hz}, 2 \mathrm{H}), 7.64(\mathrm{~d}, \mathrm{~J}=12 \mathrm{~Hz}, 1 \mathrm{H}), 8.31(\mathrm{~d}$, $\mathrm{J}=16.2 \mathrm{~Hz}, 1 \mathrm{H}), 8.66(\mathrm{~s}, 1 \mathrm{H})$. Anal. $\left(\mathrm{C}_{9} \mathrm{H}_{10} \mathrm{~N}_{2} \mathrm{O}_{7} \mathrm{~S}\right) \mathrm{C}, \mathrm{H}, \mathrm{N}, \mathrm{S}$.

$\mathbf{N}, \mathbf{N}$-Bis(2-chloroethyl)phosphoramidic dichloride (3) was synthesized according to the published procedure ${ }^{38}$ in $84 \%$ yield.

2-(Methylthio)ethyl N,N-bis(2-chloroethyl)phosphorodiamidate (4) was synthesized by a modification of the published procedure. ${ }^{38} \mathrm{~A}$ solution of 2-(methylthio)ethanol (1.69 g, $1.7 \mathrm{~mL}, 18 \mathrm{mmol})$ in anhydrous THF (20 mL) was added dropwise to a suspension of sodium hydride $(0.74 \mathrm{~g}, 18$ $\mathrm{mmol}$; a $60 \%$ dispersion in mineral oil) in dry THF (60 mL) at ice-bath temperature with stirring over a $30 \mathrm{~min}$ period. The reaction mixture was stirred at ice-bath temperature for $3 \mathrm{~h}$. The resulting pale, cloudy suspension was added dropwise to a solution of $\mathbf{3}(4.6 \mathrm{~g}, 18 \mathrm{mmol})$ in dry THF $(50 \mathrm{~mL})$ at ice bath temperature. The reaction mixture was stirred for $4 \mathrm{~h}$ while warming to room temperature and evaporated in vacuo to give a pale yellow viscous liquid. This liquid was dissolved in $\mathrm{CH}_{2} \mathrm{Cl}_{2}(50 \mathrm{~mL})$ and bubbled with ammonia for $45 \mathrm{~min}$ at room temperature. The resulting milky liquid was evaporated in vacuo and diluted with anhydrous diethyl ether $(50 \mathrm{~mL})$, and the resulting precipitates were filtered. The filtrate was evaporated in vacuo to yield a viscous, yellow oil. The crude product was purified on a flash column with eluent EtOAc to give $1.4 \mathrm{~g}$ ( $22 \%$ yield) of $\mathbf{4}$ as a yellow oil: TLC $\mathrm{R}_{\mathrm{f}} 0.53 \mathrm{in}$ EtOAc; ${ }^{1} \mathrm{H} N M R\left(\mathrm{CDCl}_{3}\right) \delta 2.07(\mathrm{~s}, 3 \mathrm{H}), 2.66(\mathrm{t}, \mathrm{J}=9 \mathrm{~Hz}, 2 \mathrm{H})$, $3.00-3.66(\mathrm{~m}, 8 \mathrm{H}), 4.07(\mathrm{q}, \mathrm{J}=10.4 \mathrm{~Hz}, 2 \mathrm{H})$.

2-(Methylsulfonyl)ethyl N,N-bis(2-chloroethyl)phosphorodiamidate (5) was prepared from 4 on a $2.0 \mathrm{mmol}(0.7$ g) scale as described in $\mathbf{2}$ with the same quantities of aqueous $\mathrm{H}_{2} \mathrm{O}_{2}$ (30 wt \%, $21 \mathrm{~mL}, 200 \mathrm{mmol}$ ) and $0.3 \mathrm{M}$ ammonium molybdate $(3 \mathrm{~mL})$ used in the procedure. The product was obtained as a viscous, yellow oil that was crystallized from anhydrous diethyl ether to give $0.35 \mathrm{~g}$ ( $50 \%$ yield) of 5 as white solids: $\mathrm{mp} 83-86{ }^{\circ} \mathrm{C}$; TLC $\mathrm{R}_{\mathrm{f}} 0.45$ in EtOAC/EtOH (10:1); ${ }^{1 \mathrm{H}}$ $\mathrm{NMR}\left(\mathrm{CDCl}_{3}\right) \delta 3.0(\mathrm{~s}, 3 \mathrm{H}), 3.11-3.90,(\mathrm{~m}, 10 \mathrm{H}), 4.39(\mathrm{q}, \mathrm{J}=$ $6.6 \mathrm{~Hz}, 2 \mathrm{H})$. Anal. $\left(\mathrm{C}_{7} \mathrm{H}_{17} \mathrm{Cl}_{2} \mathrm{~N}_{2} \mathrm{O}_{4} \mathrm{SP}\right) \mathrm{C}, \mathrm{H}, \mathrm{Cl}, \mathrm{N}, \mathrm{S}$.

2-(Methylsulfonyl)ethyl N,N-bis(2-chloroethyl)phosphorodiamidate (6) was synthesized according to published procedure ${ }^{39}$ with some modifications. A solution of 2-(methylsulfonyl)ethanol $(3.72 \mathrm{~g}, 30 \mathrm{mmol})$ and triethylamine $(3.10 \mathrm{~g}$, $30 \mathrm{mmol}$ ) in $\mathrm{CH}_{2} \mathrm{Cl}_{2}(30 \mathrm{~mL})$ was added dropwise to a solution of phosphorus oxychloride $(4.60 \mathrm{~g}, 30 \mathrm{mmol})$ in $\mathrm{CH}_{2} \mathrm{Cl}_{2}(50 \mathrm{~mL})$ at ice-bath temperature over a 20 min period. The resulting mixture was stirred at room temperature for $1 \mathrm{~h}$ and then cooled in an ice-bath. 2-Chlorothylamine monohydrogen chloride $(6.96 \mathrm{~g}, 60 \mathrm{mmol}$ ) was added, followed by a dropwise addition of triethylamine $\left(12.2 \mathrm{~g}, 120 \mathrm{mmol}\right.$ ) solution in $\mathrm{CH}_{2} \mathrm{Cl}_{2}$ $(40 \mathrm{~mL})$ over a $40 \mathrm{~min}$ period. The reaction mixture was stirred overnight at room temperature, and the resulting white solids were filtered off. The filtrate was washed with $5 \% \mathrm{HCl}(50$ $\mathrm{mL}), 5 \% \mathrm{NaHCO}_{3}(50 \mathrm{~mL})$, and saturated brine $(2 \times 100 \mathrm{~mL})$, dried over anhydrous $\mathrm{Na}_{2} \mathrm{SO}_{4}$, and filtered. The filtrate was evaporated in vacuo, and the crude residue was purified on a flash column with eluent EtOAc/EtOH (10:1) to give a colorless oil. The oil was crystallized with EtOAc/hexane to obtain 1.1 $\mathrm{g}\left(11 \%\right.$ yield) of 6 as white solids: $\mathrm{mp} 58-60^{\circ} \mathrm{C}$; TLC $\mathrm{R}_{\mathrm{f}} 0.43$ in EtOAc/EtOH (10:1); ${ }^{1} \mathrm{H} N M R\left(\mathrm{CDCl}_{3}\right) \delta 3.0(\mathrm{~s}, 3 \mathrm{H}), 3.07-$ $3.77(\mathrm{~m}, 12 \mathrm{H}), 4.45(\mathrm{q}, \mathrm{J}=8.8 \mathrm{~Hz}, 2 \mathrm{H})$. Anal. $\left(\mathrm{C}_{7} \mathrm{H}_{17} \mathrm{Cl}_{2} \mathrm{~N}_{2} \mathrm{O}_{4}\right.$ SP) $\mathrm{C}, \mathrm{H}, \mathrm{Cl}, \mathrm{N}, \mathrm{S}$.

2-(Methylthio)ethyl $\mathbf{N}, \mathbf{N}, \mathbf{N}^{\prime}, \mathbf{N}^{\prime}$-tetrakis(2-chloroethyl)phosphorodiamidate (7) was prepared according to published procedure ${ }^{40}$ with some modifications. Phosphorus trichloride $\left(5.0 \mathrm{~mL}, 2.0 \mathrm{M}\right.$ in $\mathrm{CH}_{2} \mathrm{Cl}_{2}, 10.0 \mathrm{mmol}$ ) was diluted in $\mathrm{CH}_{2} \mathrm{Cl}_{2}$ (100 mL) and cooled to $0{ }^{\circ} \mathrm{C}$ (ice-salt bath). Bis(2chloroethyl)amine hydrochloride $(3.57 \mathrm{~g}, 20.0 \mathrm{mmol}$ ) was added to the solution, followed by a dropwise addition of triethylamine $(8.3 \mathrm{~mL}, 60.0 \mathrm{mmol})$ in $45 \mathrm{~mL}$ of $\mathrm{CH}_{2} \mathrm{Cl}_{2}$ over a period of $45 \mathrm{~min}$. 2-(Methylthio)ethanol $(0.83 \mathrm{~g}, 9.0 \mathrm{mmol})$ dissol ved in $\mathrm{CH}_{2} \mathrm{Cl}_{2}$ (15 mL) was added rapidly from a dropping funnel and the mixture stirred at $0{ }^{\circ} \mathrm{C}$ for $45 \mathrm{~min}$. The reaction mixture was cooled to $-24{ }^{\circ} \mathrm{C}$ (dry ice- $\mathrm{CCl}_{4}$ bath), and tertbutyl hydroperoxide $(7.6 \mathrm{~mL}, 3.0 \mathrm{M}$ in 2,2,4-trimethylpentane, $22.0 \mathrm{mmol}$ ) was added. The mixture was then allowed to warm to room temperature. Subsequently, EtOAc $(150 \mathrm{~mL})$ was added to the pale yel low reaction mixture, and the resulting white solids were filtered. The filtrate was evaporated in vacuo to give a yell ow oily residue. The residue was dissolved in 50 $\mathrm{mL}$ of $\mathrm{CH}_{2} \mathrm{Cl}_{2}$ and washed with cold $5 \% \mathrm{HCl}(3 \times 50 \mathrm{~mL})$ and cold $5 \%$ NaHCO3 $(3 \times 50 \mathrm{~mL})$. The organic layer was dried over anhydrous sodium sulfate and evaporated in vacuo to yield the crude product as a yellow oil. The crude material was purified on a flash column with eluent EtOAc/hexanes 
(1:1) to afford $1.0 \mathrm{~g}$ ( $23 \%$ crude yield) of slightly impure 7 as a colorless, viscous oil: TLC $\mathrm{R}_{\mathrm{f}} 0.43$ in EtOAc/hexane (1:1); ${ }^{1} \mathrm{H} \mathrm{NMR}\left(\mathrm{CDCl}_{3}\right) \delta 2.13(\mathrm{~s}, 3 \mathrm{H}), 2.73(\mathrm{t}, \mathrm{J}=6.8 \mathrm{~Hz}, 2 \mathrm{H}), 3.10-$ $3.90(\mathrm{~m}, 16 \mathrm{H}), 4.12(\mathrm{q}, \mathrm{J}=8.6 \mathrm{~Hz}, 2 \mathrm{H})$.

2-(Methylsulfonyl)ethyl $\mathbf{N}, \mathbf{N}, \mathbf{N}^{\prime}, \mathbf{N}^{\prime}$-tetrakis(2-chloroethyl)phosphorodiamidate (8) was prepared from $\mathbf{7}$ on a $2.3 \mathrm{mmol}(0.98 \mathrm{~g})$ scale, as described in $\mathbf{2}$ with the same quantities of aqueous $\mathrm{H}_{2} \mathrm{O}_{2}$ (30 wt \%, $21 \mathrm{~mL}, 200 \mathrm{mmol}$ ) and $0.3 \mathrm{M}$ ammonium molybdate $(3 \mathrm{~mL})$ used in the procedure. Crude product was obtained as a colorless, oily residue. This was purified on a flash column with eluent EtOAc to remove impurities and then $\mathrm{EtOH}$ to obtain $0.6 \mathrm{~g}$ (overall $12 \%$ yield) of 8 as white solids: $\mathrm{mp} 98-101{ }^{\circ} \mathrm{C}$; TLC $\mathrm{R}_{\mathrm{f}} 0.41$ in EtOAc; ${ }^{1} \mathrm{H} \mathrm{NMR}\left(\mathrm{CDCl}_{3}\right) \delta 2.95(\mathrm{~s}, 3 \mathrm{H}), 3.03-3.83,(\mathrm{~m}, 18 \mathrm{H}), 4.45(\mathrm{q}$, $\mathrm{J}=8.6 \mathrm{~Hz}, 2 \mathrm{H})$. Anal. $\left(\mathrm{C}_{11} \mathrm{H}_{23} \mathrm{Cl}_{4} \mathrm{~N}_{2} \mathrm{O}_{4} \mathrm{SP}\right) \mathrm{C}, \mathrm{H}, \mathrm{Cl}, \mathrm{N}, \mathrm{S}$.

2-Hydroxypropyl Methyl Sulfide (9). A mixture of 1-mercapto-2-propanol $(2.00 \mathrm{~g}, 22 \mathrm{mmol})$ and $10 \mathrm{M} \mathrm{NaOH}(2.2$ $\mathrm{mL}, 22 \mathrm{mmol}$ ) were added dropwise to a solution of methyl iodide $(5.00 \mathrm{~g}, 35 \mathrm{mmol})$ in $100 \mathrm{~mL}$ of $\mathrm{MeOH}$ with stirring over a $25 \mathrm{~min}$ period. The reaction mixture was stirred at room temperature for $2 \mathrm{~h}$ and then $\mathrm{MeOH}$ evaporated at atmospheric pressure. The residue was poured in water $(100 \mathrm{~mL})$ and extracted with di ethyl ether $(3 \times 100 \mathrm{~mL})$. The combined ether extract was washed with saturated brine $(2 \times 50 \mathrm{~mL})$, dried over anhydrous $\mathrm{MgSO}_{4}$, and filtered. The filtrate was evaporated in vacuo to give $1.0 \mathrm{~g}$ (41\% yield) of 9: TLC $R_{f} 0.42$ in EtOAc/hexane (1:4), $\mathrm{I}_{2}$ as indicator; ${ }^{1} \mathrm{H} \mathrm{NMR}\left(\mathrm{CDCl}_{3}\right) \delta 1.28$ $(\mathrm{q}, \mathrm{J}=5.4 \mathrm{~Hz}, 3 \mathrm{H}), 2.13(\mathrm{~s}, 3 \mathrm{H}), 2.59(\mathrm{~d}, \mathrm{~J}=13.2 \mathrm{~Hz}, 2 \mathrm{H})$, 3.35-4.20 (m, 1H).

1-Methyl-2-(methylthio)ethyl N,N-bis(2-chloroethyl)phosphorodiamidate (10) was prepared from 9 on a 30 $\mathrm{mmol}(3.18 \mathrm{~g}$ ) scale as in the synthesis of $\mathbf{4}$ to give a yellow liquid crude product. This was purified on a flash column with eluent $\mathrm{CH}_{2} \mathrm{Cl}_{2} / \mathrm{EtOH}$ (20:1) to give $2.2 \mathrm{~g}$ (24\% yield) of pure 10 as a yellow oil. The product was obtained as a mixture of two diastereoi somers with very close $R_{f}$ values: TLC $R_{f 1} 0.43$ and $\mathrm{R}_{\mathrm{f} 2} 0.38$ in $\mathrm{CH}_{2} \mathrm{Cl}_{2} / \mathrm{EtOH}(20: 1) ;{ }^{1} \mathrm{H} \mathrm{NMR}\left(\mathrm{CDCl}_{3}\right) \delta 1.42$ $(\mathrm{d}, \mathrm{J}=4.8 \mathrm{~Hz}, 3 \mathrm{H}), 2.15(\mathrm{~s}, 3 \mathrm{H}), 2.66(\mathrm{~d}, \mathrm{~J}=16.2 \mathrm{~Hz}, 2 \mathrm{H})$, 3.40-3.70 (m, 8H) , 4.58-4.67 (m, $1 \mathrm{H})$. Anal. $\left(\mathrm{C}_{8} \mathrm{H}_{19} \mathrm{Cl}_{2} \mathrm{~N}_{2} \mathrm{O}_{2^{-}}\right.$ SP) C, H, Cl, N, S.

1-Methyl-2-(methylsulfonyl)ethyl N,N-bis(2-chloroethyl)phosphorodiamidate (11) was prepared from 10 on a 1 $\mathrm{mmol}(0.31 \mathrm{~g})$ scale as described in the synthesis of $\mathbf{2}$ with the same quantities of aqueous $\mathrm{H}_{2} \mathrm{O}_{2}$ (30 wt \%, $21 \mathrm{~mL}, 200 \mathrm{mmol}$ ) and $0.3 \mathrm{M}$ ammonium molybdate $(3 \mathrm{~mL})$ used in the procedure. Pure 11 was obtained as $0.3 \mathrm{~g}$ (yield $88 \%$ ) of a light yellow oil as a mixture of diastereoisomers: TLC $R_{\mathrm{f} 1} 0.54$ and $R_{\mathrm{f} 2} 0.50$ in $\mathrm{CH}_{2} \mathrm{Cl}_{2} / \mathrm{EtOH}(10: 1) ;{ }^{1} \mathrm{H}$ NMR $\left(\mathrm{CDCl}_{3}\right) \delta 1.55(\mathrm{~d}, \mathrm{~J}=8.4$ $\mathrm{Hz}, 3 \mathrm{H}), 3.12(\mathrm{~s}, 3 \mathrm{H}), 3.20-3.85(\mathrm{~m}, 10 \mathrm{H}), 4.94-5.16(\mathrm{~m}, 1 \mathrm{H})$. Anal. $\left(\mathrm{C}_{8} \mathrm{H}_{19} \mathrm{Cl}_{2} \mathrm{~N}_{2} \mathrm{O}_{4} \mathrm{SP}\right), \mathrm{C}, \mathrm{H}, \mathrm{Cl}, \mathrm{N}, \mathrm{S}$.

2-Methylthio-1-phenylethanol (12) was synthesized according to published procedure $\mathrm{e}^{41}$ in $43 \%$ yield.

1-Phenyl-2-(methylthio)ethyl $\mathbf{N}, \mathbf{N}, \mathbf{N}^{\prime}, \mathbf{N}^{\prime}$,-tetrakis(2chloroethyl)phosphorodiamidate (13) was prepared with the use of $\mathbf{1 2}$ on a $9 \mathrm{mmol}(1.5 \mathrm{~g})$ scale as described previously in the synthesis of 7. The crude product was purified on a flash column with EtOAc/hexane (3:7) eluent to give $2.5 \mathrm{~g}(65 \%$ yield) of 13 as a yellow oil: TLC $R_{f} 0.66$ in EtOAc/hexane (1:1); ${ }^{1} \mathrm{H}$ NMR $\left(\mathrm{CDCl}_{3}\right) \delta 1.99(\mathrm{~s}, 3 \mathrm{H}), 2.65-3.80(\mathrm{~m}, 18 \mathrm{H})$, 5.13-5.60 (m, 1H), $7.31(\mathrm{~s}, 5 \mathrm{H})$.

1-Phenyl-2-(methylsulfonyl)ethyl $\mathbf{N}, \mathbf{N}, \mathbf{N}^{\prime}, \mathbf{N}^{\prime}$,-tetrakis(2-chloroethyl)phosphorodiamidate (14) was prepared from 13 on a $1.6 \mathrm{mmol}(0.83 \mathrm{~g})$ scale as described in $\mathbf{2}$ with the same quantities of aqueous $\mathrm{H}_{2} \mathrm{O}_{2}$ (30 wt \%, $21 \mathrm{~mL}, 200$ $\mathrm{mmol}$ ) and $0.3 \mathrm{M}$ ammonium molybdate $(3 \mathrm{~mL})$ used in the procedure. Crude product was obtained as a yellow oil. This was purified on a flash column with EtOAc/hexane (1:1) as eluent to obtain $0.6 \mathrm{~g}$ ( $63 \%$ yield) of $\mathbf{1 4}$ as a yellow oil: TLC $\mathrm{R}_{\mathrm{f}}$ 0.31 in EtOAc/hexane (1:1); ${ }^{1} \mathrm{H}$ NMR $\left(\mathrm{CDCl}_{3}, 360 \mathrm{MHz}\right) \delta 2.80$ $(\mathrm{s}, 3 \mathrm{H}), 2.90-3.90(\mathrm{~m}, 18 \mathrm{H}), 5.68-6.20(\mathrm{~m}, 1 \mathrm{H}), 7.45(\mathrm{~m}, 5 \mathrm{H})$. Anal. $\left(\mathrm{C}_{17} \mathrm{H}_{27} \mathrm{Cl}_{4} \mathrm{~N}_{2} \mathrm{O}_{4} \mathrm{SP}\right) \mathrm{C}, \mathrm{H}, \mathrm{Cl}, \mathrm{N}, \mathrm{S}$.

2-(Phenylthio)ethyl N,N'-bis(2-chloroethyl)phosphorodiamidate (15) was synthesized according to the procedure in 6 with some modifications. A mixture of 2-(phenylthio)- ethanol $(4.70 \mathrm{~g}, 30 \mathrm{mmol})$ and $E t_{3} \mathrm{~N}(3.10 \mathrm{~g}, 30 \mathrm{mmol})$ in benzene $(30 \mathrm{~mL})$ was added dropwise to a stirred solution of phosphorus oxychloride $(4.60 \mathrm{~g}, 30 \mathrm{mmol})$ in benzene $(50 \mathrm{~mL})$ at ice-bath temperature over $30 \mathrm{~min}$. The resulting mixture was stirred for $40 \mathrm{~min}$ at room temperature and then cooled in ice-bath. 2-Chloroethylamine hydrochloride $(6.96 \mathrm{~g}, 60$ $\mathrm{mmol}$ ) was added to the solution, followed by a dropwise addition of $\mathrm{Et}_{3} \mathrm{~N}(12.1 \mathrm{~g}, 120 \mathrm{mmol})$ in $30 \mathrm{~mL}$ of $\mathrm{CH}_{2} \mathrm{Cl}_{2}$ with stirring over $30 \mathrm{~min}$. The mixture was stirred overnight at room temperature, and the resulting white solids were filtered off. The filtrate was washed with $5 \% \mathrm{HCl}(50 \mathrm{~mL}), 5 \% \mathrm{NaHCO}_{3}$ $(50 \mathrm{~mL})$, and saturated brine $(2 \times 100 \mathrm{~mL})$, dried over anhydrous $\mathrm{Na}_{2} \mathrm{SO}_{4}$, and filtered. The filtrate was evaporated in vacuo to yield crude product. The crude material was purified on a flash column with eluent E tOAc/hexane (3:1) to afford $2.0 \mathrm{~g}$ (19\% yield) of $\mathbf{1 5}$ as a colorless oil: TLC $\mathrm{R}_{\mathrm{f}} 0.45 \mathrm{in}$ EtOAc/hexane $(4: 1) ;{ }^{1} \mathrm{H} N M R\left(\mathrm{CDCl}_{3}\right) \delta 2.76-3.83(\mathrm{~m}, 10 \mathrm{H})$, $4.14(\mathrm{q}, \mathrm{J}=9.6 \mathrm{~Hz}, 2 \mathrm{H}), 7.13-7.53(\mathrm{~s}, 5 \mathrm{H})$.

2-(Phenylsulfonyl)ethyl N,N'-bis(2-chloroethyl)phosphorodiamidate (16) was prepared from 15 on a $2.6 \mathrm{mmol}$ $(1.00 \mathrm{~g})$ scal e as described in the synthesis of $\mathbf{2}$ with the same quantities of aqueous $\mathrm{H}_{2} \mathrm{O}_{2}$ (30 wt \%, $21 \mathrm{~mL}, 200 \mathrm{mmol}$ ) and $0.3 \mathrm{M}$ ammonium molybdate ( $3 \mathrm{~mL}$ ) used in the procedure. Product 16 was obtained as $1.0 \mathrm{~g}(94 \%$ yield) of white solids: $\mathrm{mp} 64-65^{\circ} \mathrm{C}$; TLC $\mathrm{R}_{\mathrm{f}} 0.52$ in EtOAc; ${ }^{1} \mathrm{H} \mathrm{NMR}\left(\mathrm{CDCl}_{3}\right) \delta 2.85-$ $3.78(\mathrm{~m}, 10 \mathrm{H}), 4.15-4.58(\mathrm{~m}, 2 \mathrm{H}), 6.88-8.15(\mathrm{~m}, 5 \mathrm{H})$. Anal. $\left(\mathrm{C}_{12} \mathrm{H}_{19} \mathrm{Cl}_{2} \mathrm{~N}_{2} \mathrm{O}_{4} \mathrm{SP}\right) \mathrm{C}, \mathrm{H}, \mathrm{Cl}, \mathrm{N}, \mathrm{S}$.

2-(p-Tolylthio)ethanol (17) was synthesized by the procedure of Amaral ${ }^{30}$ with some modifications. Aqueous $10 \mathrm{M}$ $\mathrm{NaOH}(5.6 \mathrm{~mL}, 56 \mathrm{mmol})$ was added dropwise over a $10 \mathrm{~min}$ period to a stirring mixture of 2-chloroethanol $(5.40 \mathrm{~g}, 67$ $\mathrm{mmol})$ and thiocresol $(6.95 \mathrm{~g}, 56 \mathrm{mmol})$ in ethanol $(100 \mathrm{~mL})$ kept at $40^{\circ} \mathrm{C}$. The reaction mixture was refluxed for $1 \mathrm{~h}$ and then added to 2-chloroethanol $(3.00 \mathrm{~g}, 37 \mathrm{mmol})$. Reflux was continued for additional $1 \mathrm{~h}$ and then cooled and evaporated in vacuo. The residue was partitioned between ethyl acetate $(100 \mathrm{~mL})$ and water $(100 \mathrm{~mL})$. The aqueous layer was extracted with ethyl acetate $(3 \times 100 \mathrm{~mL})$. The combined EtOAc extract was dried over anhydrous $\mathrm{Na}_{2} \mathrm{SO}_{4}$ and filtered and the filtrate evaporated in vacuo to give $9.1 \mathrm{~g}$ ( $97 \%$ yield) of 17 as a colorless oil: TLC $\mathrm{R}_{\mathrm{f}} 0.35$ in EtOAc/hexane (1:5); ${ }^{1} \mathrm{H}$ NMR $\left(\mathrm{CDCl}_{3}\right) \delta$ $2.17(\mathrm{~s}, 3 \mathrm{H}), 2.97(\mathrm{t}, \mathrm{J}=12 \mathrm{~Hz}, 2 \mathrm{H}), 3.63(\mathrm{t}, \mathrm{J}=9.9 \mathrm{~Hz}, 2 \mathrm{H})$, 6.90-7.43 (m, 4H).

2-(p-Tolylthio)ethyl N,N-bis(2-chloroethyl)phosphorodiamidate (18) was prepared with the use of 2-(p-tolylthio)ethanol (17) on a $30 \mathrm{mmol}(5.0 \mathrm{~g})$ scale as in the procedure for 4 to give $10.1 \mathrm{~g}$ of a light yellow oil.. The crude oil was purified on a flash column with eluent EtOAc/hexane $(4: 1)$ to give 6.4 $\mathrm{g}(58 \%$ yield) of $\mathbf{1 8}$ as a light yel low oil, which solidified upon overnight storage in the freezer to a white, waxlike solid: TLC $\mathrm{R}_{\mathrm{f}} 0.18$ in EtOAc/hexane (4:1); ${ }^{1} \mathrm{H} \mathrm{NMR}\left(\mathrm{CDCl}_{3}\right) \delta 2.27(\mathrm{~s}, 3 \mathrm{H})$, $2.72(\mathrm{t}, \mathrm{J}=11.1 \mathrm{~Hz}, 2 \mathrm{H}), 2.93-3.66(\mathrm{~m}, 8 \mathrm{H}), 4.08(\mathrm{q}, \mathrm{J}=8.8$ $\mathrm{Hz}, 2 \mathrm{H}), 7.06-7.40(\mathrm{~m}, 4 \mathrm{H})$.

2-(p-Tolylsulfonyl)ethyl N,N-bis(2-chloroethyl)phosphorodiamidate (19) was synthesized from 18 on a $4.0 \mathrm{mmol}$ (1.5 g) scale as in $\mathbf{2}$ with the same quantities of aqueous $\mathrm{H}_{2} \mathrm{O}_{2}$ ( $30 \mathrm{wt} \%, 21 \mathrm{~mL}, 200 \mathrm{mmol}$ ) and $0.3 \mathrm{M}$ ammonium molybdate $(3 \mathrm{~mL})$ used in the procedure. The crude product was obtained as white, waxlike solids. Upon recrystallization with EtOAc hexane, this afforded $1.4 \mathrm{~g}$ of pure 19 as white solids (87\% yield): $\mathrm{mp} 94-96{ }^{\circ} \mathrm{C}$; TLC $\mathrm{R}_{\mathrm{f}} 0.66$ in EtOAc; ${ }^{1 \mathrm{H}} \mathrm{NMR}\left(\mathrm{CDCl}_{3}\right)$ $\delta 2.45(\mathrm{~s}, 3 \mathrm{H}), 3.03(\mathrm{t}, \mathrm{J}=8.1 \mathrm{~Hz}, 2 \mathrm{H}), 3.26-3.86(\mathrm{~m}, 8 \mathrm{H})$, $4.35(\mathrm{q}, \mathrm{J}=10 \mathrm{~Hz}, 2 \mathrm{H}), 7.20-8.00(\mathrm{~m}, 4 \mathrm{H})$. Anal. $\left(\mathrm{C}_{13} \mathrm{H}_{21^{-}}\right.$ $\left.\mathrm{Cl}_{2} \mathrm{~N}_{2} \mathrm{O}_{4} \mathrm{SP}\right) \mathrm{C}, \mathrm{H}, \mathrm{Cl}, \mathrm{N}, \mathrm{S}$.

2-(p-Tolylthio)ethyl N,N'-bis(2-chloroethyl)phosphorodiamidate (20) was prepared from 17 on a $20 \mathrm{mmol}(3.36 \mathrm{~g})$ scale as described for the synthesis of $\mathbf{6}$ to give crude oil. The crude product was purified on a flash column with eluent EtOAc/hexane (3:1) to give $2.2 \mathrm{~g}$ (26\% yield) of $\mathbf{2 0}$ as a light yellow oil: TLC $R_{f} 0.52$ in EtOAc/hexane (3:1); ${ }^{1} \mathrm{H} N M R$ $\left(\mathrm{CDCl}_{3}\right) \delta 2.33(\mathrm{~s}, 3 \mathrm{H}), 2.80-3.86(\mathrm{~m}, 10 \mathrm{H}), 4.15(\mathrm{q}, \mathrm{J}=10$ $\mathrm{Hz}, 2 \mathrm{H}), 6.93-7.46(\mathrm{~m}, 4 \mathrm{H})$.

2-(p-Tolylsulfonyl)ethyl N,N'-bis(2-chloroethyl)phosphorodiamidate (21) was synthesized from $\mathbf{2 0}$ on a $2.5 \mathrm{mmol}$ 
$(1.00 \mathrm{~g})$ scale as described for $\mathbf{2}$ with the same quantities of aqueous $\mathrm{H}_{2} \mathrm{O}_{2}$ (30 wt \%, $21 \mathrm{~mL}, 200 \mathrm{mmol}$ ) and $0.3 \mathrm{M}$ ammonium molybdate $(3 \mathrm{~mL})$ used in the procedure to give $1.0 \mathrm{~g}$ (99\% yield) of $\mathbf{2 1}$ as white solids: $\mathrm{mp} 75.5-78.5^{\circ} \mathrm{C}$; TLC $\mathrm{R}_{\mathrm{f}} 0.27$ in EtOAc; ${ }^{1} \mathrm{H} N M R\left(\mathrm{CDCl}_{3}\right) \delta 2.35(\mathrm{~s}, 3 \mathrm{H}), 2.97-3.73$ $(\mathrm{m}, 1 \mathrm{OH}), 4.17-4.66(\mathrm{~m}, 2 \mathrm{H}), 7.17-7.89(\mathrm{~m}, 4 \mathrm{H})$. Anal. $\left(\mathrm{C}_{13} \mathrm{H}_{21^{-}}\right.$ $\left.\mathrm{Cl}_{2} \mathrm{~N}_{2} \mathrm{O}_{4} \mathrm{SP}\right) \mathrm{C}, \mathrm{H}, \mathrm{Cl}, \mathrm{N}, \mathrm{S}$.

2-(p-Nitrophenylthio)ethanol (22) was prepared according to the published procedure ${ }^{30}$ in $73 \%$ yield.

2-(p-Nitrophenylthio)ethyl N,N'-bis(2-chloroethyl)phosphorodiamidate (23) was prepared with the use of $\mathbf{2 2}$ on a $10 \mathrm{mmol}(1.99 \mathrm{~g})$ scale according to the method utilized for synthesis of $\mathbf{6}$, except that benzene was used as solvent instead of $\mathrm{CH}_{2} \mathrm{Cl}_{2}$. Crude product obtained as yellow oil was purified on a flash column with eluent EtOAc/hexane (1:4) to remove impurities and then EtOAc to give $1.2 \mathrm{~g}$ (30\% yield) of 23 as yellow oil: TLC $\mathrm{R}_{\mathrm{f}} 0.70$ in EtOAc; ${ }^{1} \mathrm{H} \mathrm{NMR}\left(\mathrm{CDCl}_{3}\right) \delta$ 2.93-3.76 $(\mathrm{m}, 10 \mathrm{H}), 4.16(\mathrm{t}, \mathrm{J}=9.9 \mathrm{~Hz}, 2 \mathrm{H}), 7.30-8.33(\mathrm{~m}$, $4 \mathrm{H})$.

2-(p-Nitrophenylsulfonyl)ethyl $\mathbf{N}, \mathrm{N}^{\prime}$-bis(2-chloroethyl)phosphorodiamidate (24) was prepared from $\mathbf{2 3}$ on a 1.5 $\mathrm{mmol}(0.6 \mathrm{~g})$ scale as described for $\mathbf{2}$ with the same quantities of aqueous $\mathrm{H}_{2} \mathrm{O}_{2}$ (30 wt \%, $21 \mathrm{~mL}, 200 \mathrm{mmol}$ ) and $0.3 \mathrm{M}$ ammonium molybdate ( $3 \mathrm{~mL}$ ) and reaction time of $1 \mathrm{~h}$, to give a yellow oil. Crystallization with EtOAc/hexane gave $0.5 \mathrm{~g}$ (77\% yield) of $\mathbf{2 4}$ as white solids: $\mathrm{mp} 86-88^{\circ} \mathrm{C} ; \mathrm{TLC} ; \mathrm{R}_{\mathrm{f}} 0.19$ in EtOAc; ${ }^{1} \mathrm{H}$ NMR $\left(\mathrm{CDCl}_{3}\right) \delta 2.83-3.77(\mathrm{~m}, 10 \mathrm{H}), 4.43(\mathrm{q}, \mathrm{J}$ $=9.4 \mathrm{~Hz}, 2 \mathrm{H}), 8.03-8.60(\mathrm{~m}, 4 \mathrm{H})$. Anal. $\left(\mathrm{C}_{12} \mathrm{H}_{18} \mathrm{Cl}_{2} \mathrm{~N}_{3} \mathrm{SO}_{6} \mathrm{P}\right)$ $\mathrm{C}, \mathrm{H}, \mathrm{Cl}, \mathrm{N}, \mathrm{S}$.

2-(p-Nitrophenylthio)ethyl $\mathbf{N}, \mathbf{N}, \mathbf{N}^{\prime}, \mathbf{N}^{\prime}$-tetrakis(2-chloroethyl)phosphorodiamidate (25) was prepared with the use of $\mathbf{2 2}$ on a $10 \mathrm{mmol}(1.8 \mathrm{~g})$ scale as described in the synthesis of $\mathbf{7}$ to give $5.0 \mathrm{~g}$ of yellow oil as the crude product. Initial purification with a flash column with eluents EtOAc/hexanes $(1: 2)$ and then EtOAc gave semipure product. Further purification on a flash column with EtOAc/hexane (1:1) as the eluting sol vent gave 25 as a yellow oil $\left(1.5 \mathrm{~g}, 29 \%\right.$ yield): TLC $R_{f} 0.47$ in EtOAc/hexane (1:1). ${ }^{1} \mathrm{H}$ NMR $\left(\mathrm{CDCl}_{3}\right) \delta 3.06-3.72,(\mathrm{~m}, 18 \mathrm{H})$, $4.15(\mathrm{q}, \mathrm{J}=10 \mathrm{~Hz}, 2 \mathrm{H}), 7.13-8.20(\mathrm{~m}, 4 \mathrm{H})$.

2-(p-Nitrophenylsulfonyl)ethyl $\mathbf{N}, \mathbf{N}, \mathbf{N}^{\prime}, \mathbf{N}^{\prime}$-tetrakis(2chloroethyl)phosphorodiamidate (26) was prepared from $\mathbf{2 5}$ on a $2.0 \mathrm{mmol}(1.0 \mathrm{~g})$ scale in the procedure for $\mathbf{2}$ to give crude product as a pale yellow viscous oil. The crude oil was purified using flash column chromatography with EtOAC hexane (2:1) eluent to give $0.6 \mathrm{~g}$ of pale yellow oil. Crystallization with EtOAc/hexane gave $0.6 \mathrm{~g}$ (49\% yield) of $\mathbf{2 6}$ as a white solid: $\mathrm{mp} 83-85{ }^{\circ} \mathrm{C}$; TLC $\mathrm{R}_{\mathrm{f}} 0.43$ in EtOAc/hexane $(2: 1) ;{ }^{1} \mathrm{H} \mathrm{NMR}\left(\mathrm{CDCl}_{3}\right) \delta 3.06-3.83,(\mathrm{~m}, 18 \mathrm{H}), 4.40(\mathrm{q}, \mathrm{J}=8$ $\mathrm{Hz}, 2 \mathrm{H}), 8.00-8.53(\mathrm{~m}, 4 \mathrm{H})$. Anal. $\left(\mathrm{C}_{16} \mathrm{H}_{24} \mathrm{Cl}_{4} \mathrm{~N}_{3} \mathrm{O}_{6} \mathrm{SP}\right) \mathrm{C}, \mathrm{H}$, $\mathrm{Cl}, \mathrm{N}, \mathrm{S}$.

N,N-Bis(2-chloroethyl)phosphorodiamidic acid, cyclohexylammonium salt (Phosphoramide mustard) (27) was prepared as described ${ }^{42}$ in $79 \%$ yield.

N,N'-Bis(2-chloroethyl)phosphorodiamidic acid, cyclohexylammonium salt (I sophosphoramide mustard) (28) was prepared according to a published procedure ${ }^{22}$ in $30 \%$ yield.

$\mathbf{N}, \mathbf{N}, \mathbf{N}^{\prime}, \mathbf{N}^{\prime}$-Tertakis(2-chloroethyl )phosphorodiami date phenylmethyl ester (29) was prepared from benzyl al cohol on a scale of $18 \mathrm{mmol}(1.95 \mathrm{~g})$ as described for 7. The crude material was purified on a flash column with $\mathrm{CH}_{2} \mathrm{Cl}_{2} /$ acetone (100:3) eluent to give $5.1 \mathrm{~g}$ (67\% yield) of 29 as a colorless oil: TLC Rf 0.25 in $\mathrm{CH}_{2} \mathrm{Cl}_{2}$ /acetone (100:3); ${ }^{1} \mathrm{H}$ NMR $\left(\mathrm{CDCl}_{3}\right) \delta 3.07-3.67(\mathrm{~m}, 16 \mathrm{H}), 5.07(\mathrm{~d}, \mathrm{~J}=12 \mathrm{~Hz}, 2 \mathrm{H}), 7.61$ $(\mathrm{S}, 5 \mathrm{H})$.

$\mathbf{N}, \mathbf{N}, \mathbf{N}^{\prime}, \mathbf{N}^{\prime}$-Tetrakis(2-chloroethyl)phosphorodiamidic acid, cyclohexylammonium salt (Tetrakis phosphoramide mustard) (30) was prepared by modification of a previously reported procedure. ${ }^{42}$ A solution of $29(2.0 \mathrm{~g}, 4.7$ $\mathrm{mmol}$ ) in absolute $\mathrm{EtOH}(150 \mathrm{~mL}$ ) was added to palladium on activated carbon $(0.6 \mathrm{~g}$, carbon content $10 \%)$, and the mixture was hydrogenated at room temperature and 1 atm for $2.5 \mathrm{~h}$. The reaction mixture was filtered, and then cyclohexylamine $(0.5 \mathrm{~mL})$ was added dropwise to the filtrate. The reaction solution was stirred at room temperature for $20 \mathrm{~min}$ and evaporated in vacuo to yield $1.8 \mathrm{~g}$ of grayish semisolid. A portion of crude $\mathbf{3 0}(0.15 \mathrm{~g})$ was subjected to preparative TLC and developed with EtOAC. The TLC region containing the product was visualized by NBP-spray reagent, removed, and extracted with EtOAc/EtOH (1:1) to afford $0.1 \mathrm{~g}(63 \%$ yield) of 30 as a brown solid: $\mathrm{mp} 79-82{ }^{\circ} \mathrm{C} ;{ }^{1} \mathrm{H}$ NMR $\left(\mathrm{CDCl}_{3} / \mathrm{CD}_{3} \mathrm{OD}\right.$, $1: 1) \delta 2.66-3.67(\mathrm{~m}, 16 \mathrm{H}), 1.01-2.15(\mathrm{~m}, 11 \mathrm{H})\left({ }^{1} \mathrm{H}\right.$ NMR of crude 30 ).

4-Hydroperoxycyclophosphamide (31) was prepared according to published procedures ${ }^{43}$ in overall $14 \%$ yield.

Stability Studies. Stability Test of 2-(Methylsulfonyl)ethyl 2,4-dinitrophenyl Ether (2) in $0.08 \mathrm{M}$ Phosphate Buffer at $37{ }^{\circ} \mathrm{C}$ at $\mathbf{p H}$ Values of 6.4, 7.4, and 8.4. Each incubation mixture consisted of $5 \mathrm{~mL}$ of $0.08 \mathrm{M}$ phosphate buffer containing $0.2 \mathrm{mM}$ of $\mathbf{2}$. Incubations were initiated by the addition of $1 \mathrm{~mL}$ solution ( $1 \mathrm{mM}$ ) of $\mathbf{2}$ in THF to $4 \mathrm{~mL}$ of preincubated $0.1 \mathrm{M}$ phosphate buffer (pH 6.4, 7.4, or 8.4) and terminated by immediately cooling the test tubes in crushed ice. Incubations were carried out for varying time intervals in a shaking water bath at $37{ }^{\circ} \mathrm{C}$ and absorbance values measured at $359 \mathrm{~nm}$. A standard curve of 2,4-dinitrophenol at 359 $\mathrm{nm}$ was used to calculate the amount of 2,4-dinitrophenol eliminated from $\mathbf{2}$ upon incubation. Results were expressed as percent of total 2,4-dinitrophenol, where the total is represented by $0.2 \mathrm{mM}$ of 2,4-dinitrophenol. Subsequently, the percent unchanged $\mathbf{2}$ was calculated against time of incubation. The slope $\left(-k_{\text {obs }}\right)$ of a linear plot of $\ln (\%$ of $\mathbf{2}$ remaining) versus time of incubation $(\mathrm{t})$ gave the elimination rate constant $\mathrm{k}_{\text {obs. }}$. Half-life $\left(\mathrm{t}_{1 / 2}\right)$ of $\beta$-elimination was calculated by the use of equation: $t_{1 / 2}=0.693 / k_{\text {obs }}$.

Stability Test of Sulfonylethyl Phosphorodiamidate Prodrugs under Model Physiological Conditions. Stability in $0.08 \mathrm{M}$ Phosphate Buffer pH 7.4 and $37^{\circ} \mathrm{C}$. E ach incubation mixture consisted of $0.5 \mathrm{~mL}$ of $0.08 \mathrm{M}$ phosphate buffer pH 7.4 containing a 3-9 mM concentration of all test compounds, except $0.8 \mathrm{mM}$ for 14 and $0.3 \mathrm{mM}$ for 26 . Incubations were initiated with the addition of $0.1 \mathrm{~mL}$ of solution of test compound to $0.4 \mathrm{~mL}$ of preincubated $0.1 \mathrm{M}$ phosphate buffer $(\mathrm{pH} 7.4)$ in $13 \times 100 \mathrm{~mm}$ culture test tubes. Drug solutions were prepared in water (5, 6, and 11), EtOH (14 and 26), $\mathrm{EtOH} / \mathrm{H}_{2} \mathrm{O}(2: 1)\left(8\right.$ and 19), $\mathrm{EtOH} / \mathrm{H}_{2} \mathrm{O}(1: 1)(\mathbf{2 4})$ $\mathrm{EtOH} / \mathrm{H}_{2} \mathrm{O}(1: 2)(\mathbf{2 1})$, or $\mathrm{EtOH} / \mathrm{H}_{2} \mathrm{O}$ (1:3) (16). The test tubes were incubated at $37^{\circ} \mathrm{C}$ in a shaking water-bath for varying time intervals and incubations terminated with the addition of $0.5 \mathrm{~mL}$ of $2.0 \mathrm{M}$ acetate buffer $(\mathrm{pH} 5.0)$ and $2.0 \mathrm{~mL}$ of EtOH. An aliquot (16 $\mu \mathrm{L}$ for all compounds except $48 \mu \mathrm{L}$ for 14 and 26) of the resulting mixture for all samples was then spotted on a $10 \times 20 \mathrm{~mm}$ silica gel TLC plate and eluted with appropriate solvent [EtOAC/EtOH (10:1) for all analogues except EtOAc for 8 and EtOAc/hexane (3:1) for $\mathbf{1 4}$ and 26]. The starting material from all the samples either appeared as a dark spot under UV light $(\lambda=254 \mathrm{~nm})$, or the plates were subjected to NBP assay treatment to visualize the starting material $(\mathbf{5}, \mathbf{6}, \mathbf{8}, \mathbf{1 1}$, and $\mathbf{1 4})$ as a purple colored spot with varying intensity. The TLC profile of zero hour control samples in all cases did not show appearance of degradation products. The spots were then quantitatively analyzed using a Uniscan Video Densitometer. Results were expressed as the percent starting material remaining after each incubation period in comparison to the zero time incubation control sample. The slope $\left(-\mathrm{k}_{\text {obs }}\right)$ of a linear pl ot of In(\% of test compound remaining) versus time of incubation $(t)$ gave the elimination rate constant $\mathrm{k}_{\text {obs. }}$. Half-life $\left(\mathrm{t}_{1 / 2}\right)$ of $\beta$-elimination was cal culated by the use of equation: $t_{1 / 2}=0.693 / k_{\text {obs }}$.

Stability Test in the Presence of Human Plasma. Lyophilized human plasma (Sigma Chemical Co., St. Louis, MO) was used for the study and was reconstituted immediately prior to the experiments. The protocol used for the study was essentially the same as in phosphate buffer except the following:

Each incubation mixture contained $0.4 \mathrm{~mL}$ of reconstituted solution of human plasma in $0.1 \mathrm{M}$ phosphate buffer $\mathrm{pH} 7.4$, instead of the buffer alone. After the termination of the 
incubation, the test tubes were placed in crushed ice and centrifuged at high speed (4750 rpm, approximately 3000g) for $20 \mathrm{~min}$ to precipitate the proteins. Subsequently, an aliquot of the resulting supernatant was spotted on $10 \times 20 \mathrm{~mm}$ silica gel TLC plates, developed, and analyzed as described in the procedure for phosphate buffer.

In Vitro Cytotoxicity Evaluation. V-79 Chinese hamster lung fibrobl asts (American Type Culture Collection, Rockville, MD, ATCC \#93) subcloned by this laboratory were used. The procedures were similar to those reported previously. ${ }^{44}$ Cell cultures were maintained at subconfluence in a 95\% air, 5\% $\mathrm{CO}_{2}$ humidified atmosphere at $37^{\circ} \mathrm{C}$. The medium used for routine subcultivation as well as for experimental determinations was Minimum Essential Medium (Gibco, Grand Island, NY) supplemented with $10 \%$ heat-inactivated fetal bovine serum, Pen G sodium, streptomycin sulfate, amphotericin, and essential and nonessential amino acids and vitamins.

Log-phase cultures fed $24 \mathrm{~h}$ prior to use were disassociated from their growth substrate by scraping, and cells were disaggregated by repeated pi pet aspirations. Cells were counted by trypan blue dye exclusion method using a Bright-line Haemocytometer (Fisher Inc.). Polystyrene tissue culture Petri-dishes (100 mm, Costar, Cambridge, MA) were seeded with 500 cells in $10 \mathrm{~mL}$ of media and incubated for $12-15 \mathrm{~h}$ in a $95 \%$ air, $5 \% \mathrm{CO}_{2}$ humidified atmosphere. Following the initial incubation, the medium was replaced with $9.75 \mathrm{~mL}$ of fresh medium and the cells were treated with $0.25 \mathrm{~mL}$ of the drug solution in appropriate concentration or the solvent as a control. Cultures were then incubated undisturbed for $3 \mathrm{~h}$, and the drug exposure was terminated by removing the old medium and rinsing with Hank's Balanced Salt Solution (HBSS, $1 \times 10 \mathrm{~mL}$ ). The Petri-dishes were then added with fresh medium $(10 \mathrm{~mL})$ and then incubated under standard conditions, undisturbed for $5-6$ days to allow col ony formation. Colonies were then rinsed with HBSS $(2 \times 10 \mathrm{~mL})$, fixed with $95 \% \mathrm{EtOH}$, and stained with crystal violet and counted. Results were reported as the number of colonies surviving drug treatment per number of colonies in the solvent-treated control. The I $C_{50}$ values were determined by semil ogarithmically plotting the drug concentration versus cell viability as determined by the number of colonies surviving the treatments.

In Vivo Antitumor Activity. Preliminary antitumor activity of the sulfonyl analogues was evaluated against P388/0 (Wild) or P388/CPA (CP-resistant) leukemia cells in CD2F1 mice $(24-26 \mathrm{~g})$. To determine the ability of the test compounds to increase the life span of mice, animals were implanted with $10^{6}$ cells, ip, on day 0 . The drugs were either dissolved in saline or suspended in saline-Tween 80 . The mice were injected ip with drug, saline, or saline-Tween 80 on day 1 . The survival rate was compared with that of untreated controls over a 33day period. I sophosphoramide mustard (IPM) (100 mg/kg) or CP $(200 \mathrm{mg} / \mathrm{kg})$ served as a positive control. Three doses (100, 200 , and $400 \mathrm{mg} / \mathrm{kg}$ ) were used for the sulfonyl analogues. Five mice were used per dose per drug. The results were reported as \% ILS (percent increase in life span) as calculated by the following equation:

$\%$ ILS $=$ (treated median day of death/ control median day of death) $\times 100-100$

Animals living beyond 33 days were reported as "Iong term survivors" and were not used in calculations.

Acknowledgment. The authors wish to express sincere gratitude to Dr. R. F. Struck of Southern Research I nstitute, Birmingham, AL, for kindly agreeing to conduct in vivo antitumor evaluations.

Supporting Information Available: Elemental analyses data. This material is available free of charge via the Internet at http://pubs.acs.org.

\section{References}

(1) Sladek, N. E. Metabolism of oxazaphosphorines. Pharm. Ther. 1988, 37, 301-355.
(2) Ludeman, S. M. The chemistry of the metabolites of cyclophosphamide. Curr. Pharm. Des. 1999, 5, 627-643.

(3) Colvin, O. M. An overview of cyclophosphamide development and applications. Curr. Pharm. Des. 1999, 5, 555-560.

(4) Low, J. E.; Borch, R. F.; Sladek, N. E. Further studies on the conversion of 4-hydroxyoxazaphosphorines to reactive mustards and acrolein in inorganic buffers. Cancer Res. 1983, 43, 58155820.

(5) Bielicki, L.; Voelcker, G.; Hohorst, H. J . Activated cyclophosphamide: An enzyme-mechanism-based suicide inactivator of DNA polymerase/3'-5' exonuclease. J . Cancer Res. Clin. Oncol. 1984, 107, 195-198.

(6) Hohorst, H. J .; Bielicki, L.; Voelcker, G. The enzymatic basis of cyclophosphamide specificity. Adv. EnzymeRegul. 1986, 25, 99122.

(7) Kwon, C. H.; Maddison, K.; LoCastro, L.; Borch, R. F. Accelerated decomposition of 4-hydroxycyclophosphamide by human serum albumin. Cancer Res. 1987, 47, 1505-1508.

(8) Sladek, N. E. Aldehyde-dehydrogenase mediated cellular relative insensitivity to the oxazaphosphorines. Curr. Pharm. Des. 1999, $5,607-625$.

(9) Sladek, N. E.: Kollander, R.: Sreerama, L.: Kiang, D. T. Cellular levels of aldehyde dehydrogenase (ALDHIA1 and ALDH 3A1) as predictors of therapeutic responses to cyclophosphamide-based chemotherapy of breast cancer: a retrospective study Rational individualization of oxazaphosphorine-based cancer chemotherapeutic regimens. Cancer Chemother. Pharmacol. 2002, 49(4), 309-321.

(10) Ludeman, S. M.; Gamcsik, M. P. Mechanisms of resistance against cyclophosphamide and ifosfamide: can they be overcoming without sacrificing selectivity. Cancer Treat. Res. 2002, 112, 177-197.

(11) Bunting, K. D.; Townsend, A. J . De novo expression of transfected human class 1 aldehyde dehydrogenase (ALDH) causes resistance to oxazaphosphorine anti-cancer alkylating agents in hamster V-79 cell lines. Elevated class 1 ALDH activity is closely correlated with reduction in DNA interstarnd cross-linking and lethality. J . Biol. Chem. 1996, 271, 11884-11890.

(12) Dittrich, C. I fosfamide: actual data, new insights, and persisting questions. Semin. Oncol. 2000, 27 (1 Suppl. 1), 1-2.

(13) Fleming, R. A. An overview of cyclophosphamide and ifosfamide pharmacology. Pharmacotherapy 1997, 17 (5 Pt 2), 146S-154S.

(14) Kerbusch, T.; de Kraker, J .; Keizer, H. J .; van Putten, J. W.; Groen, H. J .; J ansen, R. L.; Schellens, J. H.; Beijnen, J. H. Clinical pharmacokinetics and pharmacodynamics of ifosfamide and its metabolites. Clin. Pharmacokinet. 2001, 40 (1), 41-62.

(15) Boddy, A. V.; Yule, S. M. Metabolism and pharmacokinetics of oxazaphosphorines. Clin. Pharmacokinet. 2000, 38 (4), 291-304.

(16) Woodland C.; Ito, S.; Granvil, C. P.; Wainer, I. W.; Klein, J .; Koren, G. Evidence of renal metabolism of ifosfamide to nephrotoxic metabolites. Life Sci. 2000, 68 (1), 109-117.

(17) Dubourg, L.; Michoudet, C.; Cochat, P.; Baverel, G. Human kidney tubules detoxify chloroacetal dehyde, a presumed nephrotoxic metabolite of ifosfamide. J . Am. Soc. Nephrol. 2001, 12 (8), $1615-1623$.

(18) Springate, J . E. I fosfamide metabolite chloroacetal dehyde causes renal dysfunction in vivo. J. Appl. Toxicol. 1997, 17 (1), 75-79.

(19) Sood, C.; O'Brien, P. J . 2-Chloroacetal dehyde-induced cerebera glutathione depletion and neuroxicity. Br. J . Cancer 1996, 27, S287-S293.

(20) McVay, J. I.; Wood, A. M. Suspected ifosfamide-induced neurotoxicity. Pharmacotherapy 1999, 19(12), 1450-1455.

(21) Friedman, O. M.; Wodinsky, I.; Myles, A. Cyclophosphamide (NSC-26271)-related phosphoramide mustards-Recent advances and historical perspective. Cancer Treat. Rep. 1976, 60, 337346.

(22) Struck, R. F.; Dykes, D. J .; Corbett, T. H.; Suling, W. J .; Trader, M. W. I sophosphoramide mustard, a metabolite of ifosfamide with activity against murine tumors comparable to cyclophosphamide. Br. J. Cancer 1983, 47, 15-26.

(23) Kwon, C.-H.; Borch, R. F. Effects of N-substitution on the activation mechanisms of 4-hydroxycyclophosphamide analogues. J . Med. Chem. 1989, 32, 1491-1496.

(24) Brock, N. Comparative pharmacological study in vitro and in vivo with cyclophosphamide (NSC-26271), cyclophosphamide metabolites, and plain nitrogen mustard compounds. Cancer Treat. Rep. 1976, 60, 301-307.

(25) Boal, J . H.; Ludeman, S. M.; Ho, C. K.; Engel, J .; Niemeyer, U Direct detection of the intracellular formation of carboxy phosphamide using nuclear magnetic resonance spectroscopy. Arzneim-Forsch. 1994, 44 (1), 84-93.

(26) Struck, R. F. Aldophosphamide: Synthesis, characterization and comparison with "Hohorst's aldophosphamide". Cancer Treat. Rep. 1976, 60, 317-319.

(27) Kader, A. T.; Stiriling, C. J . M. Elimination-addition. Part III New procedures for the protection of amino groups. J . Chem. Soc. 1964, 258-268. 
(28) Hardy, P. M.; Rydon, H. N.; Thompson, R. C. The use of $\beta$-methylthioethyl esters for the protection of carboxyl groups in peptide synthesis: removal through the $\beta$-methylsulphonylethyl ester. Tetrahedron Lett. 1968, 21, 2525-2526.

(29) Tesser, G. I.; Balvert-Geers, I. C. The methylsulfonylethyloxycarbonyl group, new and versatile amino protective function. J. Pept. Protein Res. 1975, 7, 295-305.

(30) Amaral, M. J. S. A. The 2-(p-nitrophenylthio)ethyl group for carboxy-group protection in peptide synthesis. J . Chem. Soc. (C) 1969, 2495-2497.

(31) Crosby, J .; Stirling, C. J . M. Elimination and addition reactions Part XIX. Elimination of phenoxide from $\beta$-substituted ethyl phenyl ethers: the nature of activation in 1,2-elimination. J Chem. Soc. B 1970, 671-679.

(32) Crosby, J ;; Stirling, C. J . M. Elimination and addition reactions. Part XIX. Elimination of phenoxide from $\beta$-substituted ethy phenyl ethers: Evidence for E 1cB mechanism. J . Chem. Soc. B 1970, 679-686.

(33) Marshall, D. R.; Thomas, P. J .; Stirling, C. J . M. Elimination and addition reactions. Part 32. Discrimination between concerted and stepwise processes in activated elimination reactions. J. Chem. Soc., Perkin Trans. 2 1977, 1913-1919.

(34) Ludeman, S. M.; Boyd, V. L.; Regan, J . B.; Gallo, K. A.; Zon, G.; I shii, K. Synthesis and antitumor activity of cyclophosphamide analogues. 4. Preparation, kinetic studies, and anticancer screening of "phenylketophosphamide" and similar compounds related to the cyclophosphamide metabolite aldophosphamide J. Med. Chem. 1986, 29, 716-727.

(35) Borch, R. F.; Valente, R. R. Synthesis, activation and cytotoxicity of aldophosphamide analogues. J . Med. Chem. 1991, 34, 30523058.
(36) Barlow, K. N.; Marshall, D. R.; Stirling, C. J . M. Elimination and Addition Reactions. Part 33. Formation of carbanions derived from sulphones and nitriles bearing $\beta$-onium substituents. J . Chem. Soc., Perkin Trans. 2 1977, 1920-1928.

(37) Whalley, W. B. Organic Fluoro-compounds. Part II. The preparation of alkyl 2:4-dinitrophenyl ethers from 1-fluoro-2:4-dinitrobenzene. J . Chem. Soc. 1950, 2241-2243.

(38) Friedman, O. M.; Seligman, A. M. Preparation of N-Phosphorylated derivatives of bis- $\beta$-chloroethylamine. J . Am. Chem. Soc. 1954, 76, 655-658.

(39) Misiura, K.; Okruszek, A.; Pankiewicz, K, Stec, W. J .; Czownicki Z.; Utracka, B. Stereospecific synthesis of chiral metabolites of ifosfamide and their determination in the urine. J . Med. Chem. 1983, 26, 674-679.

(40) Mulcahy, R. T.; Gipp, J . J .; Schmidt, J . P.; J oswig, C.; Borch, R. F. Nitrobenzyl phosphorodiamidates as potential hypoxia-selective alkylating agents. J. Med. Chem. 1994, 37, 1610-1615

(41) Conte, V.; Di Furia, F.; Licini, G.; Modena, G.; Sbampato, G. Vallr, G. Enantioselective oxidation of $\beta$-hydroxythioethers Synthesis of optically active alcohols and epoxides. Tetrahedron: Asymmetry 1991, 2 (4), 257-276.

(42) Friedman, O. M.; Boger, E.; Grubliauskas, V.; Sommer, H. Synthesis of $\mathrm{N}$-phosphorylated derivatives of nitrogen mustards with latent cytotoxicity. J . Med. Chem. 1963, 6, 50-58.

(43) Borch, R. F.; Millard, J. A. The mechanism of activation of 4-hydroxycyclophosphamide. J. Med. Chem. 1987, 30, 427-431.

(44) Kwon, C.-H.; Moon, K.-Y.; Baturay, N.; Shirota, F. Chemically stable, lipophilic prodrugs of phosphoramide mustard as potential anticancer agents. J. Med. Chem. 1991, 34 (2), 588-592.

J M0304764 